\title{
Mid-Holocene regional reorganization of climate variability
}

\author{
K. W. Wirtz ${ }^{1}$, K. Bernhardt ${ }^{1,2}$, G. Lohmann ${ }^{3}$, and C. Lemmen ${ }^{1}$ \\ ${ }^{1}$ GKSS Research Center Geesthacht, Institute for Coastal Research, Max-Planck Straße 1, \\ 21501 Geesthacht, Germany \\ ${ }^{2}$ Carl-von-Ossietzky Universität Oldenburg, Institute for Chemistry and Biology of the Marine \\ Environment (ICBM), Carl-von-Ossietzky Straße, 26111 Oldenburg, Germany \\ ${ }^{3}$ Alfred Wegener Institute for Polar and Marine Research, P.O. Box 180, \\ 27483 Bremerhaven, Germany
}

Received: 12 December 2008 - Accepted: 12 December 2008 - Published: 28 January 2009 Correspondence to: K. W. Wirtz (wirtz@gkss.de)

Published by Copernicus Publications on behalf of the European Geosciences Union.

Mid-Holocene climate reorganization

K. W. Wirtz et al.

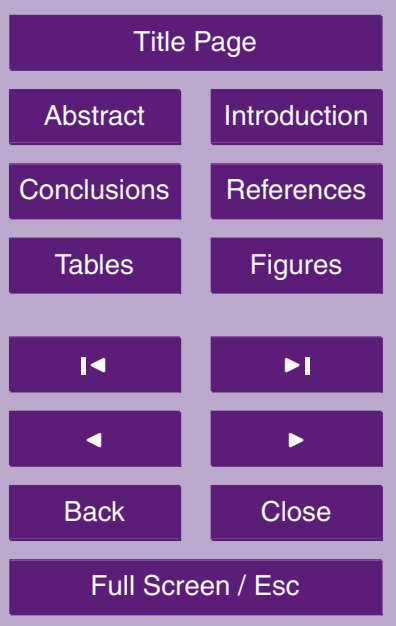

Printer-friendly Version

Interactive Discussion 


\section{Abstract}

We integrate 130 globally distributed proxy time series to refine the understanding of climate variability during the Holocene. Cyclic anomalies and temporal trends in periodicity from the Lower to the Upper Holocene are extracted by combining Lomb5 Scargle Fourier-transformed spectra with bootstrapping. Results were cross-checked by counting events in the time series. Main outcomes are: First, the propensity of the climate system to fluctuations is a region specific property. Many records of adjacent sites reveal a similar change in variability although they belong to different proxy types (e.g., $\delta^{18} \mathrm{O}$, lithic composition). Secondly, at most sites, irreversible change occured

10 in the Mid-Holocene. We suggest that altered ocean circulation together with slightly modified coupling intensity between regional climate subsystems around the $5.5 \mathrm{kyr}$ BP event (termination of the African Humid Period) were responsible for the shift. Fluctuations especially intensified along a pan-American corridor. This may have led to an unequal crisis probability for early human civilizations in the Old and New World. Our 15 study did not produce evidence for millennial scale cyclicity in some solar activity proxies for the Upper Holocene, nor for a privileged role of the prominent 250, 550, 900 and $1450 \mathrm{yr}$ cycles. This lack of global periodicities corroborates the regional character of climate variability.

\section{Introduction}

20 There was hardly any period in Earth's history that experienced more stability in the climate system than did the Holocene. According to Richerson et al. (2001), even the onset of human civilizations is owed to the lack of large climate fluctuations, since change was the constant rule for all preceding glacial as well as interglacial periods within the Quaternary. The notion of a stable Holocene climate has been, meanwhile, questioned by many researchers (e.g. Fairbridge and Hillaire-Marcel, 1977; Bond et al., 1997c; Mayewski et al., 2004). Refined accuracy of paleorecords and of noise reduc-
5, 287-326, 2009

Mid-Holocene climate reorganization

K. W. Wirtz et al.

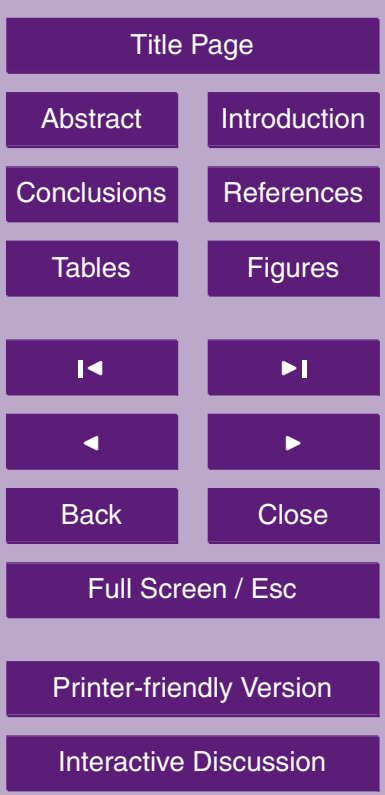


tion methods has disclosed a series of distinct shifts from most proxies for the last 11,500 years (Barber et al., 2004; Kim et al., 2007). These shifts attract further attention for at least four reasons.

1. Disruptions have - with the exceptions of the Saharan desertification at $5500 \mathrm{yr}$ BP (Claussen et al., 1999) and the $8.2 \mathrm{kyr}$ event (Renssen et al., 2001) - not yet been reproduced by numerical modeling. Mechanistic understanding of the complex interplay between ice, ocean, atmosphere and vegetation bundled in regional climate sub-systems is far from being complete (Steig, 1999).

2. We also still lack knowledge about the spatial extension of prominent disruptions (deMenocal et al., 2000b; Sirocko, 2003; Mayewski et al., 2004). So far, only the work of Rimbu et al. (2004) based on 18 records of alkenone sea surface temperature worldwide revealed consistent regional differences of climate variability.

3. Holocene climate fluctuations define the range of natural variability to which the signatures of anthropogenic interference with the Earth system should be compared (von Storch et al., 2004; Moberg et al., 2005). Attribution and analysis of past shifts is pivotal for assessing ongoing changes, as well as reproduction of recorded natural variability (of the Holocene) by models is a prerequisite for simulating future climates (in the Anthropocene).

4. Another motivation to seek for past, but not too remote alterations, especially in regional temperature or moisture is the "breeding" role of the Holocene for civilizations. While its stability has been claimed to be responsible for their rising, instabilities are first candidates for explaining their collapses. This idea is reflected by numerous studies where individual outbreaks in proxy time series have been correlated with eclipses of ancient empires (Fagan, 1999; Anderson, 2001; deMenocal, 2001; Binford, 2001). Provoked by the simplicity of this approach, a large group of historical scientists dislike such intrusion by geoscience into their discipline (Erickson, 1999; Coombes and Barber, 2005).
5, 287-326, 2009

Mid-Holocene climate reorganization

K. W. Wirtz et al.

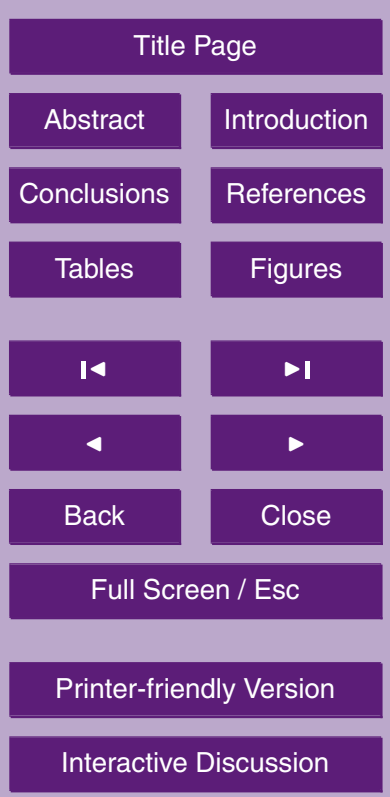

Interactive Discussion

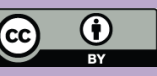


Fragmented (model) knowledge and controversy are hence characterizing both the effects as well as causes of singular Holocene climate shifts. Evidence for the nearly regular cyclicity of events, however, seems to be firm. Predominant modes of punctuated disruptions on millennial time scales have since long been identified (e.g. Fair5 bridge and Hillaire-Marcel, 1977). For the North Atlantic, the $1450 \mathrm{yr}$ periodicity was proposed by Bond et al. (1997c), and is relevant in tropical regions as well (deMenocal et al., 2000b; Thompson et al., 2003b). On the centennial time scale, recurrent climate anomalies were detected by McDermott et al. (2001) or Sarnthein et al. (2003b). Often, an external trigger was suspected behind the quasi-cyclicity - above all variations of 10 solar activity (e.g., Hodell et al., 2001c; Bond et al., 2001c).

Spectral analysis can indicate system properties of the global climate (like stability, turn-over times, regularity of modes) and helps to identify active teleconnections which are generated by the coupling of sub-systems and their feed-backs. If extended to external forcings, analysis in the frequency domain will shed light on the possible ori15 gin of shifts. Sensitivity to variable forcing can, for example, be estimated using the quantitative relationship of spectral intensities (Debret et al., 2007). We here provide such a reconstruction of the spectral behavior inherent to climate proxy time series with global coverage and for the entire Holocene. Former data reviews were mostly centered around an eventual synchronicity or spatial intensity of shifts (e.g. Mayewski et al., 2004; Seppä et al., 2007), while spectral synthesis studies cover either a single climate zone or a shorter interval within the Holocene (e.g. Morrill et al., 2003; Moberg et al., 2005).

Here, a spectral analysis technique is introduced that is adapted to unravel the temporal wax and wane of dominant fluctuation modes. Operating with this tool on a global 25 set of proxy time series, we not only aim to address the question of how quasi-cyclic modes were distributed worldwide and which factors could be tentatively claimed being responsible for them. Acknowledging the observation that millennial as well as centennial modes are discontinuous or even missing in a number of high-resolution records (e.g. Noren et al., 2002b; Moberg et al., 2005), our study focuses on temporal and spa-

Mid-Holocene climate reorganization

K. W. Wirtz et al.

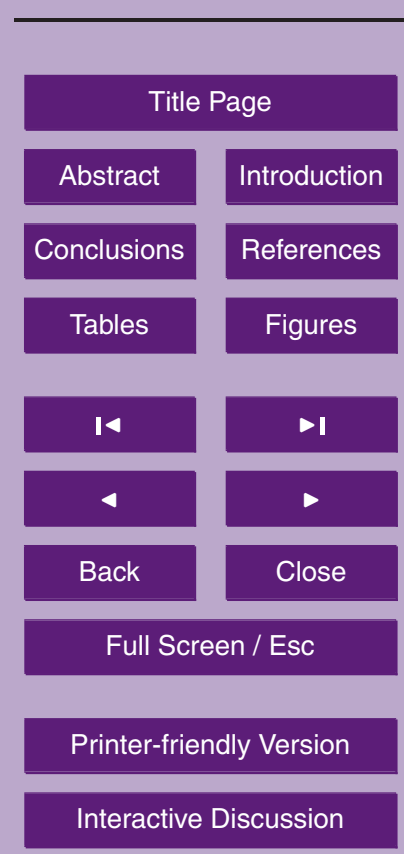

Interactive Discussion

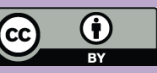


tial trends in the intensity of climate fluctuation modes. The study of variability trends in time and space reflects in particular the questions: Has the climate system of the Holocene continuously stayed in a unique state? Does its stability (sensu retaining of large shifts) as well as instability (disposition to minor fluctuations) reflect a global 5 property or distinct regional features?

\section{Selection of proxy data}

In total 130 long-term high-resolution time series obtained at 109 globally distributed sites were collected from existing literature. Due to low sedimentation rate resulting in coarse temporal resolution, open ocean locations are underrepresented with respect 10 to coasts and land masses (Fig. 1). $77 \%$ of the records have temporal resolution better than $100 \mathrm{yr}$ and $80 \%$ span more than $9000 \mathrm{yr}$ within the period $12 \mathrm{kyr} \mathrm{BP}$ to the present (see Table 1 and 2). 68 data sets are accessible from one of the Publishing Network for Geoscientific \& Environmental Data (PANGEA, www.pangea.de) or the National Climate Data Center (NOAA NCDC, www.ncdc.noaa.gov). The remaining time series were digitized with an error of less than $2 \%$ from original publications .

We chose to analyze time series based on quantities that serve as proxies for temperature, effective moisture (i.e. precipitation - evaporation), and rarely also wind regime, not unlike Mayewski et al. (2004). Records were excluded which involve more complex relationships to climate, such as productivity or stable carbon isotopes. The types of records are broadly categorized in Table 1 into (1) isotope fractionation, mostly $\delta^{18} \mathrm{O}$, (2) lithic composition, and (3) relative species abundance (tree pollen or algae). In addition, solar activity was inferred from ${ }^{10} \mathrm{Be}$ abundance and ${ }^{14} \mathrm{C}$ flux (Bond et al., 2001c).
5, 287-326, 2009

Mid-Holocene climate reorganization

K. W. Wirtz et al.

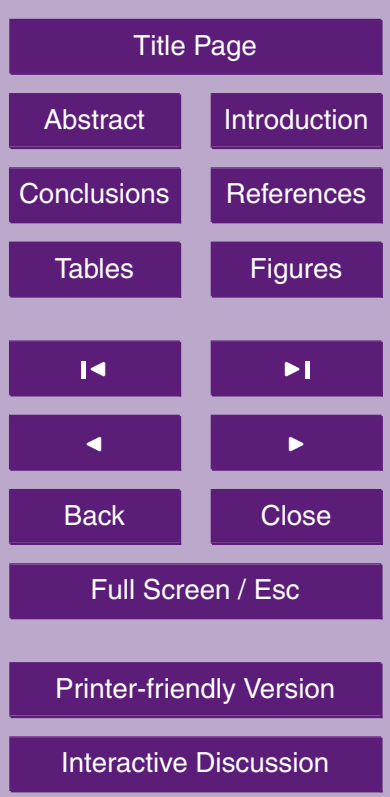


We employ a spectral analysis since this approach is not sensitive against possible absolute dating errors. Spectral information can be interpreted independently from the different and sometimes uncertain correlations of individual variables with the climate 5 state (like for isotope fractionation in ice cores, lake or marine sediments, or pollen composition) what allows to use a broader spectrum of proxy types. If one is in particular interested in the temporal change of power spectra, wavelet transformation is usually the method of choice (Moy et al., 2002; Moberg et al., 2005). However, wavelets require evenly sampled time-series, while time sequences of proxy records are mostly 10 irregular. To avoid the introduction of a spectral bias by interpolation and, in addition, to make the method also applicable to records with relatively few samples, we base our approach on the procedure suggested by Schulz and Mudelsee (2002).

This means to employ a Lomb-Scargle Fourier transform followed by a bias correction with correction factor obtained from a theoretical red-noise spectrum 15 which, in turn, is rooted on a Monte-Carlo ensemble of 1000 first order autoregressive processes. We use version 3.5 of the software package REDFIT (www.ncdc.noaa.gov/paleo/softlib/redfit/redfit.html) with parameters ofac=4, hifac=0 and two Welch windows with an overlap of $50 \%$, and assume a $95 \%$ confidence level for identifying significant spectral anomalies. For time series with a small fraction $(n)$ of data points in each Welch window, we follow the recommendation by Thomson (1990) and take $1-1 / n$ as the threshold for significance.

Acknowledging the notion of a globally visible Mid-Holocene climatic change (e.g. Steig, 1999; Morrill et al., 2003) we split the time series into two overlapping intervals; these intervals (12-5.5 kyr BP and 6.5-0 kyr BP) will be referred to as Lower and Upper 25 Holocene, respectively. The initial age $12 \mathrm{kyr}$ BP compromises between the different starting points of the time-series which in some cases reflect the globally asynchronous onset of the Holocene. The exact choice of the starting age, however, was not found to be critical for our analysis.

5, 287-326, 2009

Mid-Holocene climate reorganization

K. W. Wirtz et al.

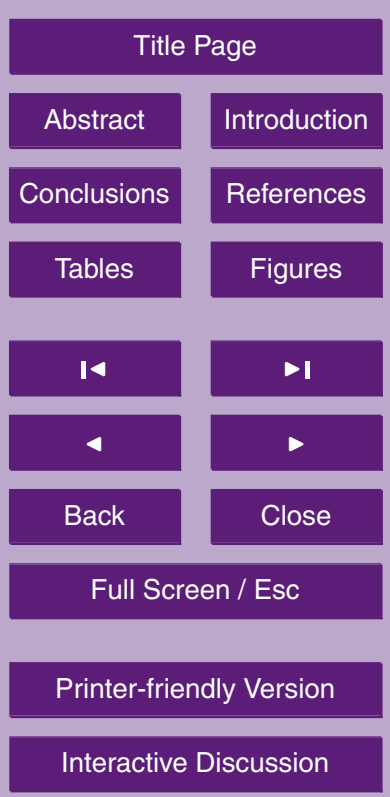

Interactive Discussion

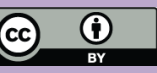


In order to diagnose the change in spectral intensity from Lower to Upper Holocene we employ a selective bootstrap. Randomly chosen data points were substituted with also randomly chosen values from the same part (Lower/Upper Holocene). Subsequently, the spectrum is examined for changes in significance. We obtained good re5 sults for 5000 realizations with substitution fraction of $33 \%$ for each time series. From this we statistically identified local long-term changes in the variability signal. Either for the entire spectrum or for a frequency window we checked whether its spectral significance is sensitive to bootstrapping. If a mode looses significance by bootstrapping in the upper interval, but endures changes in the lower part, this corresponds to a positive 10 change in cyclicity (periodic signal originates from the Upper Holocene part of the timeseries). The opposite behavior (sensitivity in bootstrapping the lower and robustness in the upper time interval) is attributed to a negative temporal trend.

Spatial clustering of locations is performed by radially extrapolating the peak intensity / from each record location with exponential decrease $(/ \cdot \exp (-r / 1500 \mathrm{~km}))$. Peak 15 intensity is a binary measure with $I=1$ if at site $i$ the sum of all available local proxy information significantly indicates the presence/increase of frequencies, and $I=-1$ for negative trends.

\subsection{Non-cyclic event frequency}

The analysis in the frequency domain is cross-checked by a simple counting method 20 relying on a straightforward definition of climate events. After removal of the $2 \mathrm{kyr}$ running mean, the time series are normalized by their standard deviation. Frequency peaks are considered as a distinct event if (1) they exceed a threshold $p_{a}$ and (2) are separated by a zero-line crossing to the preceding event. By using in parallel a vector of thresholds $p_{a}=1.5^{-1,0,1,2}$ the method is made robust with respect to the choice of ${ }_{25} p_{a}$. The non-cyclic event frequency is calculated as the average number of events for different thresholds $p_{a}$, divided by the length of the time period.
$5,287-326,2009$

Mid-Holocene climate reorganization

K. W. Wirtz et al.

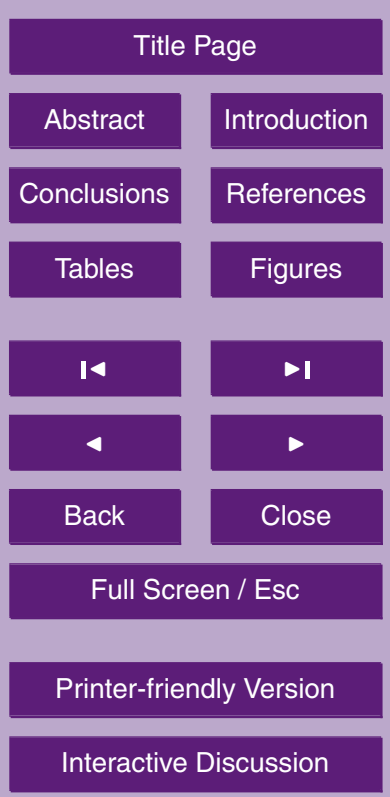

Interactive Discussion

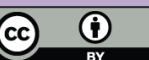




\section{Results}

\subsection{Mid-Holocene change in climate modes}

The way how changes in the spectral intensity are detected by our method is visualized in Fig. 2 for three selected records, i.e. temperature reconstruction for Southeast Eu5 rope, $\delta^{18} \mathrm{O}$ at Sajama, Bolivia, and solar activity from Greenland ice cores. Only those frequency peaks that are with $95 \%$ probability not compatible with red noise mark a significant mode. Random displacement of proxy values in one half of the Holocene dampens some of those modes, as, for example, obvious for the 1/340 yr cycles in Southeast Europe temperature during the Upper Holocene. For isotopic oxygen at 10 Sajama, spectral changes are manifold. The 1/900 yr mode vanishes when either of the two halves is distorted by bootstrapping, and the two prominent centennial cycles (1/250 yr, 1/200 yr) appear in the Upper Holocene only. In this period, the well known $1000 \mathrm{yr}$ mode of solar activity turns out to be absent. Just by visual inspection, one could suspect its presence in the Lower Holocene according to the relatively high spectral intensity, the value of which, however, is below the critical threshold for significance.

Apart from the three example records, we detected in all 130 time series 223 significant modes in the spectral interval between 1/200 yr and 1/1800 yr (see also Fig. 3). When contrasting Lower with Upper Holocene, 62 of these peaks gain significance while 24 loose it. We also checked for prominent frequencies: neither the presence of modes nor their changes did accumulate in particular spectral windows. Instead, we found a relatively flat histogram of significant frequency bands (Fig. 3).

\subsection{Regional clustering of spectral properties}

Only a minority of sites reveal significant modes in the Lower Holocene. After applying the clustering algorithm, absence of oscillations is globally the norm except for small regions in the North Atlantic (tropical western and northern parts), East Africa and Antarctica (red areas in Fig. 4). In the Upper Holocene, North Atlantic and in

5, 287-326, 2009

Mid-Holocene climate reorganization

K. W. Wirtz et al.

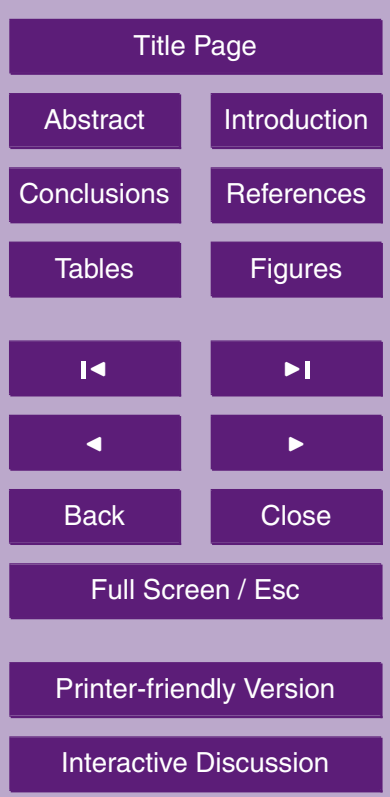

294 
particular eastern American sites with dominant modes build large regional clusters. The global distribution of locations with changes in spectral modes displayed in Fig. 5 demonstrates that these are remarkably homogeneous within these regional clusters. Clusters are generally made out of about 4-9 sites with independent proxy records 5 which, in their large majority, exhibit the same spectral trend.

Obviously, damping or amplification of a climate fluctuation mode is only modestly affected by the heterogeneous quality of records, inherent random noise or other local phenomena. The spectral differences between the two selected temperature related records shown above, i.e. for Southeast Europe and Bolivia, can therefore be extrapo10 lated to collections of large areas at sub-continental scale. Like for the two centennial cycles at Sajama, new modes appear during the Mid-Holocene in North and entire South-West America, East and North Atlantic and East Asia. Contrary, climate fluctuations fade out in eastern South America/West Atlantic, the Arctic, East Africa and, to some extent also South-East Asia.

15 The spatial organization of clusters persist after mapping the change for two frequency sub-domains. In Fig. 6, Mid-Holocene trends separated according centennial and millennial cycles still occur in great spatial uniformity. Since the total band-width is higher for all centennial modes, their global trend pattern also largely resemble the one for the entire frequency band $(1 / 200 \mathrm{yr}-1 / 1800 \mathrm{yr})$, with the exception that the disappearance of regular climate shifts in the East Atlantic is less pronounced. The clustering in Fig. 5 as well as the differentiated spectral map (Fig. 6) reveal a clear longitudinal pattern. For example, nearly all East Pacific sites become more oscillatory while the contrary happened for the entire Southwest Atlantic. Overall, cycles with periods smaller than $850 \mathrm{yr}$ are more likely to be enhanced in the Upper Holocene compared to millenial modes.

\subsection{Cross-validation with trends in non-cyclic event frequency}

Our second indicator for the spatio-temporal organization of climate variability which is the density change in non-cyclic events from the first to the second half of the Holocene,

5, 287-326, 2009

Mid-Holocene climate reorganization

K. W. Wirtz et al.

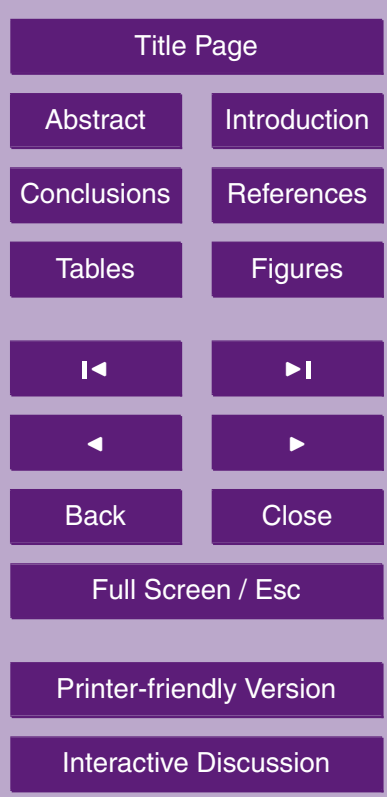


turns out to be spatially coherent as well (Fig. 7). Though, the longitudinal separation for non-cyclic frequency change is differently oriented compared to the Lomb-Scargle derived trends in Fig. 5. Abundance of climatic shifts is, for example, decreasing in East Asia where due to the spectral picture one would expect an increase. However, 5 the pronounced Mid-Holocene enhancement of climate variability in a Pan-American corridor is equally reproduced, and the increase in periodic spectral power in the East Atlantic corridor is corroborated for the southern part. The analysis of non-cyclic events also confirms spatial patterns in centennial spectral trends (Fig. 6, left).

10 From the literature on Holocene climate variability one could expect that at least four frequencies play a privileged role in our spectral analysis. The two millennial scale oscillations which comprise the $900 \mathrm{yr}$ periodicity extracted in the GISP2 $\delta^{18} \mathrm{O}$ records by Schulz and Paul (2002); Rimbu et al. (2004) and the classical 1450 yr period (e.g. O'Brien et al., 1995) are points of reference for many paleo-proxy studies. In addi15 tion, a $320 \mathrm{yr}$ and a $550 \mathrm{yr}$ cycle have been repeatedly observed in proxy records as well as output of general circulation models (GCM) with reduced complexity (Weijer and Dijkstra, 2003; Weber et al., 2004; Te Raa and Dijkstra, 2003). However, none of the four modes arose more prominently than others within our global study. The most robust result, instead, derives from an apparent non-stationary of regular climate

oscillations. Only about $10 \%$ of spectral peaks are stable, i.e. found over the entire period as well as after partial boostrapping. This substantiates our hypothesis that around the $5.5 \mathrm{kyr}$ event (termination of the African Humid Period) the climate system may have undergone an irreversible re-organization. So far, non-stationary variability has only been reported for regional systems, like the Southern Pacific with its decadal

\section{Spectral divorce at Mid-Holocene}

5, 287-326, 2009

Mid-Holocene climate reorganization

K. W. Wirtz et al.

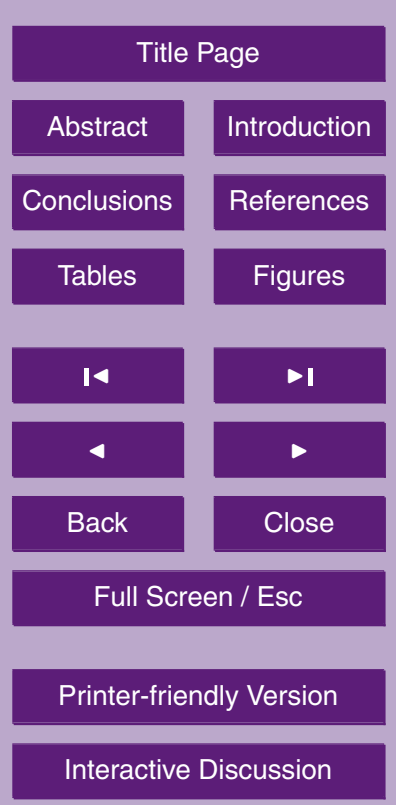
2002). Previous review studies, however, weren't aware of the global dimension of the re-organization between Lower and Upper Holocene. One reason for this may be the 
reference character of Greenland and the North Atlantic. Records from this area show persistent millennial cycles (Bond et al., 1997c), in contrast to nearly all other locations around the globe. There, a temporal switch of modes is more often found than their persistence.

5 A second major outcome of our study is the regional uniformity of temporal trends. Although coverage of many regions is yet much below a value that allows for statistically firm conclusions, the similar, albeit not equal, global distribution of changes in periodic (Fig. 5 as well as non-periodic (Fig. 7) modes and the consistent clustering of adjacent sites which, in general, comprise different proxy types, should be taken 10 as a strong indication for a regionalization of variability modes. Equal trends are even more homogeneously clustered for non-periodic climate variability. They remarkably differ from cyclic trends in Eurasia. Nevertheless, all modes (centennial, millennial and non-cyclic) intensified during the Holocene in a longitudinal zone crossing the Peruvian upwelling area and North-east America. A counterexample, though, against spatial uni15 formity is evident through the scatter of modal trends within the East Asian monsoon system. This may be due to its internal complexity and various active teleconnections to which the monsoon is sensitive. For example, it has been speculated that the atmospheric connection between the western Asian monsoon and the thermohaline circulation (THC) in the North Atlantic decreased in intensity from the Lower to the Upper Holocene (Morrill et al., 2003). This might explain a reduced correlation between trends in millenial and non-cyclic modes in the two climate sub-systems observed in our study.

\section{Possible mechanisms for variability changes}

In face of the fragmented understanding of the mechanisms producing climate shifts 25
5, 287-326, 2009

Mid-Holocene climate reorganization

K. W. Wirtz et al.

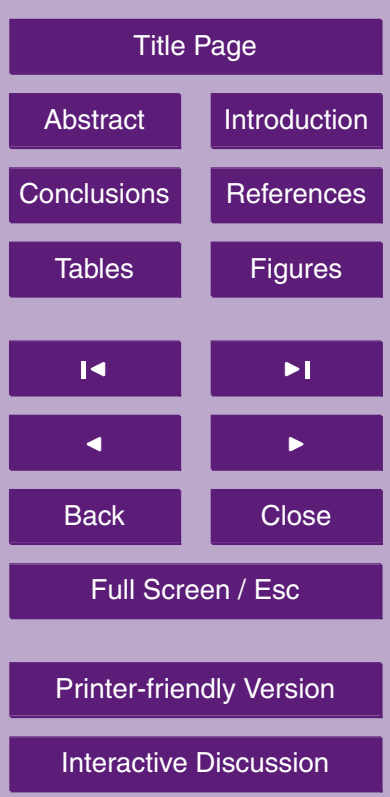
may have caused their temporal change or their regional organization. We here only briefly discuss the possible role of ocean and atmospheric circulation, and of external 
forcings.

The sun's influence on Holocene climate variability has been deduced from the synchronicity of climate anomalies and variations in solar activity (e.g. Bond et al., 2001c; Hodell et al., 2001c). Our analysis includes records of cosmogenic nuclide production $5 \quad\left({ }^{10} \mathrm{Be}\right.$ and ${ }^{14} \mathrm{C}$ flux) as well as reconstructed sunspot number of ?, and shows persistence of the $208 \mathrm{yr}$ Suess cycle together with a damping of millennial modes after 6 kyr BP (Fig. 2 and yellow sun in Figs. 5-6). A recent analysis of the sunspot number power spectrum (Dima and Lohmann, 2005) identified periods of 6,500, 2,500, 950 and 550 yr. Debret et al. (2007) already questioned the hypothesis of Bond et al. (2001a) 10 that the $1500 \mathrm{yr}$ cycles are due to variations in solar activity. Still, the possibility of solar variability being amplified by oceanic feedbacks can not be entirely excluded (Renssen et al., 2006).

Central in the literature discussion is the THC, which is connected to North Atlantic deep water formation. The THC is commonly considered the primary process for the 15 generation of climate fluctuations on interdecadal or centennial (Broecker et al., 1985) as well as millennial time scales (Stocker et al., 1992; Weijer and Dijkstra, 2003). Schulz and Paul (2002), however, questioned its connection with the prominent $1450 \mathrm{yr}$ oscillation. The Iceland-Scotland overflow water is an important component of the thermohaline circulation. Its record contains dominant periodicities of 1,400 and 700 years 20 associated with THC variations over the Holocene (Bianchi and McCave, 1999). It is conceivable that ocean circulation changes, like those of the Atlantic multidecadal oscillations, modulate SST variability in the North Atlantic basin on centennial and longer timescales. Particular THC variations are detected for the Mid-Holocene in the ocean circulation through hydrographic changes (Rühlemann et al., 2004), which were more 25 pronounced in the early Holocene (Kim et al., 2007).

To understand the atmospheric circulations related to Holocene variability, one can look for analogous patterns during the instrumental period. This procedure was used to explore the physical processes producing SST patterns and thereby to understand recorded Holocene SST changes (Marchal et al., 2002; Rimbu et al., 2004; Lorenz

5, 287-326, 2009

Mid-Holocene climate reorganization

K. W. Wirtz et al.

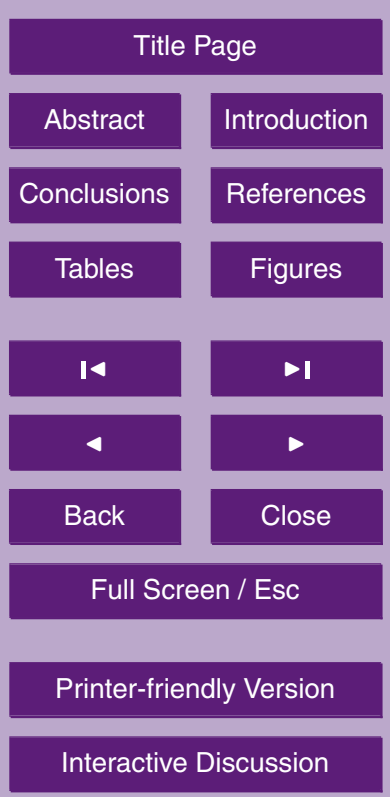


et al., 2006). The spatial pattern of Northern Hemisphere SST reconstructions for the Holocene emphasizes a North Atlantic Oscillation trend towards its negative phase, a feature which can be reproduced by a coupled climate model (Lorenz and Lohmann, 2004). This trend is overlaid by 2,400 and $900 \mathrm{yr}$ cycles (Rimbu et al., 2004), consistent 5 with other proxy data sets and solar variation.

Other mechanisms behind temporally changing modes include (1) high frequency "noise" (2) low frequency orbital forcing, and (3) particular events. The Pacific decadal oscillation and the EI Niño-Southern Oscillation (ENSO) show long-term enhancement (Moy et al., 2002; Rimbu et al., 2004). The origin of high frequency fluctuations is 10 controversially discussed but a combination of nonlinear oceanographic interactions in the tropical Pacific and orbital forcing well fits into model-based and instrumental evidence (Clement et al., 1999; Loubere et al., 2003). These fluctuations may have activated multicentennial modes (Simmonds and Walland, 1998). Phase transitions in climate sub-systems could also be triggered by a slow change in insolation. Given the 15 wider distribution of millennial modes after the cessation of oscillations in solar activity at $6 \mathrm{kyr}$ BP, we suggest that the Mid-Holocene reversal of insolation change differently affected regional subsystems. As a result, oceanic or atmospheric teleconnections between subsystems could have weakened or strengthened. Such shifts were possibly mediated by dislocations of convergence zones or trade winds, thereby modifying the damping and amplification forces of modes (Lohmann and Lorenz, 2007).

Intensification of ENSO in the Mid-Holocene, with a progressive increase in frequency to periodicities of 2 to 8.5 years, is believed to mark the onset of modern-day precipitation patterns in low-latitude regions (Rodbell et al., 1999). Analysis of archives in northern Africa indicate strong reductions in tropical trees and Sahelian grassland 25 cover, which allowed large-scale dust mobilization after $4300 \mathrm{yr}$ BP (Kropelin et al., 2008). Haug et al. (2001) found a large transition (in the frequency space) at Cariaco Basin 3800 years ago indicative for tropical reorganization of the hydrological cycle. Similar millennial-scale hydrologic variability is reported at other locations (Koutavas et al., 2002; Ekdahl et al., 2005).
5, 287-326, 2009

Mid-Holocene climate reorganization

K. W. Wirtz et al.

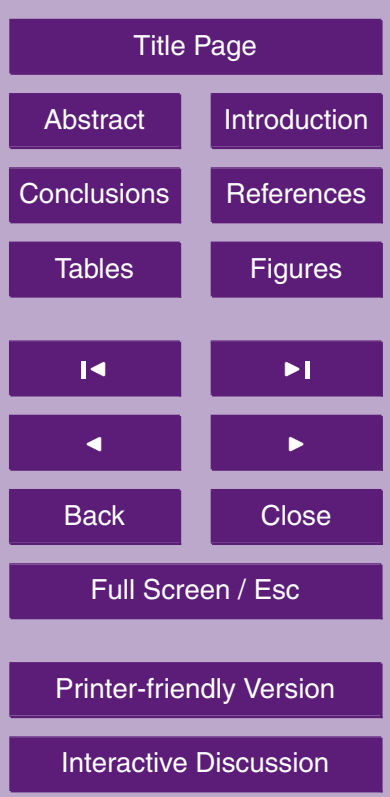

Interactive Discussion

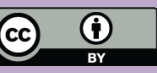


Most of the transitions overstress the capabilities of concurrent climate models, but it is useful to compare the induced variability with internal oscillatory modes (without external trigger) which are seen in models of reduced complexity (Mikolajewicz and Maier-Reimer, 1990; Weijer and Dijkstra, 2003). Model perturbation experiments re5 veal eigenmodes on millennial time scales. These modes are generated by the advection of buoyancy anomalies around the overturning loop, both in a single-hemispheric basin leading to centennial modes or throughout the global ocean responsible for millennial cycles. The most negative eigenvalues (strongest damping) was found for centennial oscillations (Weijer and Dijkstra, 2003; Te Raa and Dijkstra, 2003). However, 10 such modes could be activated if fluctuations in radiative energy input are included into simulation studies (Weber et al., 2004).

\section{Consequences for cultural development?}

The evidence that climate variability was not uniformly distributed over the globe, gains a new aspect to the dispute of whether or how Holocene climate affected the develop15 ment of human societies. We propose that frequency of climate changes rather than average characteristics made an effective difference between inhabited world regions. In particular cultures situated in the Pan-American corridor have seen a significant rise in event frequency by about two additional disruptions more per millenium after 6 kyr BP. It is well imaginable that increased climate variability meant an elevated stress 20 fects of singular events. In western Asia, like in many other world regions, the proba-
bility of climatic shifts (also visible as centennial modes) declined over the Holocene. Ancient civilizations in the Near East or later in southern Europe were challenged by abrupt climatic changes and resulting subsistence crises with much lower frequency. In

Pullitzer price winning work, J. Diamond related the lagged development between Old and New World before the colonization era to differences in biodiversity determined by the geographical orientation of the Americas with respect to Eurasia (Diamond,
5, 287-326, 2009

Mid-Holocene climate reorganization

K. W. Wirtz et al.

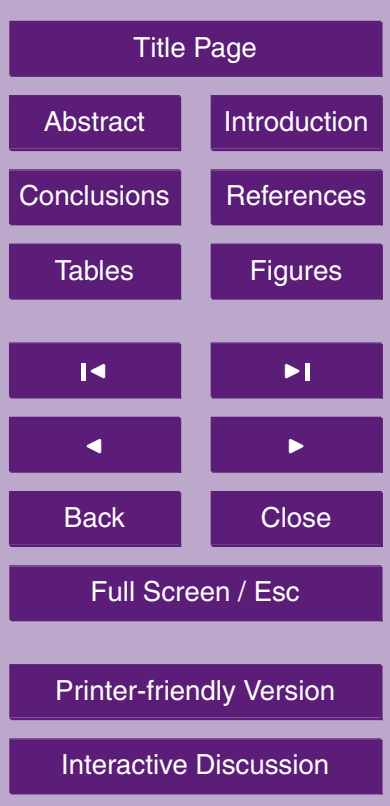

Interactive Discussion

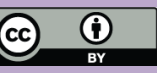


1999). We here suggest that climate variability should be taken into consideration in these conceptual approaches and also in quantitative approaches to simulating the effect of climate on human prehistory (e.g., Wirtz and Lemmen, 2003).

\section{Conclusions}

5 Our analysis substantiates two hypotheses. First, the propensity of the climate system to amplify external fluctuations or to endogenously generate them is not a global property, but differs among regions. Secondly, most regional propensities underwent a irreversible change during the Mid-Holocene. Fluctuations especially intensified along a Pan-American corridor. This eventually led to an unequal probability of crisis for early human civilizations in the Old and New World.

Our study did not produce evidence for millennial scale cyclicity in solar activity proxies for the Upper Holocene, nor for a privileged role of the prominent 250, 550, 900 and $1450 \mathrm{yr}$ cycles. This finding corroborates the regional nature of climate variability. It seems likely that altered ocean circulation together with slightly modified coupling 15 intensity between subsystems (regional interplay of ice, ocean, atmosphere and vegetation) after the $5.5 \mathrm{kyr}$ BP event made these subsystems either more or less prone to oscillations. The discussion of possible mechanisms behind changed climate variability, however, has to be substantiated by future modelling studies.

Acknowledgements. We thank Karin Holmgren, Detlef Gronenborn, Hans von Storch, Den20 nis Bray, Victor Brovkin for helpful comments on an earlier version of the manuscript. Sabrina Solms and Sonja Dorendorf are acknowledged for assisting with the compilation of data and literature. C. L. was supported by the Deutsche Forschungsgemeinschaft (DFG priority program INTERDYNAMIK) and the Dutch Agency for Environmental Assessment (MNP Bilthoven).
5, 287-326, 2009

Mid-Holocene climate reorganization

K. W. Wirtz et al.
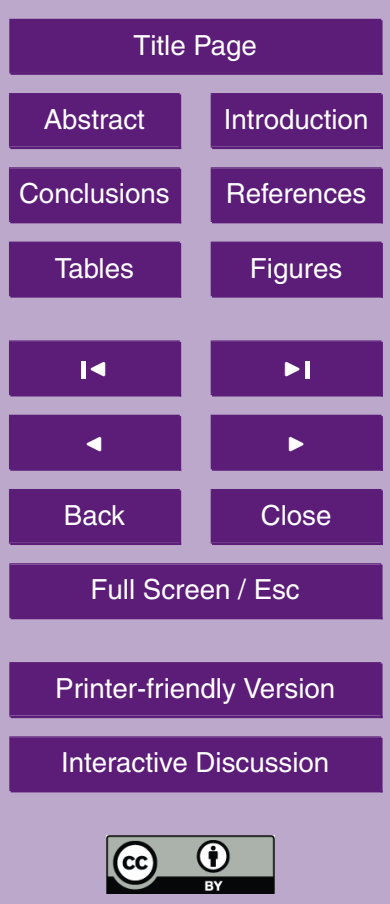


\section{References}

Abbott, M., Binford, M. W., Brenner, M., Curtis, J. H., and Kelts, K. R.: A 3,500 ${ }^{14}$ Cyr high-resolution sediment record of lake level changes in Lake Titicaca, Bolivia/Peru, Quatern. Res., 47, 169-180, 1997. 318

5 Anderson, D. G.: Climate and culture change in Prehistoric and Early Historic North America, Archaeol. Eastern N. Am., 29, 143-186, 2001. 289

Andreev, A., Tarasov, P., Siegert, C., Ebel, T., Klimanov, V., Melles, M., Hahne, J., Shilova, G., Dereviagin, A., and Hubberten, H.-W.: Vegetation and climate changes on the northern Taymyr, Russia during the Upper Pleistocene and Holocene reconstructed from pollen records, Boreas, 32, 484-505, 2003. 319

Arz, H. W., Gerhardt, S., Pätzold, J., and Röhl, U.: Millennial-scale changes of surface- and deep-water flow in the western tropical Atlantic linked to Northern Hemisphere high-latitude climate during the Holocene, Geology, 29, 239-242, 2001. 318

Bahr, A., Lamy, F., Arz, H., Kuhlmann, H., and Wefer, G.: Late glacial to Holocene climate and sedimentation history in the NW Black Sea, Mar. Geol., 214, 309-322, 2005. 318

Bar-Matthews, M., Ayalon, A., Kaufman, A., and Wasserburg, G. J.: The Eastern Mediterranean paleoclimate as a reflection of regional events: Soreq cave, Israel, Earth and Planet. Sci. Lett., 166, 85-95, 1999. 318

Barber, D., Dyke, A., Hillaire-Marcel, C., Jennings, A., Andrews, J., et al.: Forcing of the cold event of 8200 years ago by catastrophic drainage of Laurentide lakes, Nature, 400, 344-348, 1999. 318

Barber, K., Zolitschka, B., Tarasov, P., and Lotter, A. F.: Atlantic to Urals - the Holocene climatic record of Mid-Latitude Europe, in: Past Climate Variability through Europe and Africa, edited by R.W. Battarbee, F. G. and Stickley, C., vol. 6 of Developments in Paleoenvironmental Research, Springer, Dordrecht, 2004. 289

Barker, P. A., Street-Perrott, F. A., Leng, M. J., Greenwood, P. B., Swain, D. L., Perrott, R. A., Telford, R. J., and Ficken, K. J.: A 14000 -Year Oxygen Isotope Record from Diatom Silica in Two Alpine Lakes on Mt. Kenya, Science, 292, 2307-2310, 2001. 318, 319

Benson, L., Kashgarian, M., Rye, R., Lund, S., Paillet, F., Smoot, J., Kester, C., Mensing, S., Meko, D., and Lindström, S.: Holocene multidecadal and multicentennial droughts affecting Northern California and Nevada, Quatern. Sci. Rev., 21, 659-682, 2002. 318

Bianchi, G. and McCave, I.: Holocene periodicity in North Atlantic climate and deep-ocean flow

Mid-Holocene climate reorganization

K. W. Wirtz et al.
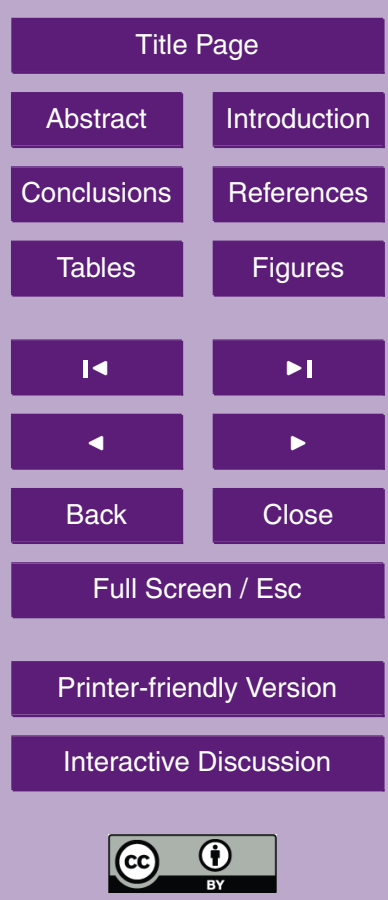
south of Iceland, Nature, 397, 515-517, 1999. 298

Binford, L. R.: Constructing Frames of Reference, University of California Press, Berkeley and Los Angeles, 2001. 289

Bond, G., Showers, W., Cheseby, M., Lotti, R., Almasi, P., deMenocal, P., Priore, P., Cullen, H., Hajdas, I., and Bonani, G.: A pervasive millennial-scale cycle in North Atlantic Holocene and glacial climates, 1257-1266, 1997a. 318

Bond, G., Showers, W., Cheseby, M., Lotti, R., Almasi, P., deMenocal, P., Priore, P., Cullen, H., Hajdas, I., and Bonani, G.: A pervasive millennial-scale cycle in North Atlantic Holocene and glacial climates, Science, 278, 1257-1266, 1997b.

10 Bond, G., Showers, W., Cheseby, M., Lotti, R., Almasi, P., deMenocal, P., Priore, P., Cullen, H., Hajdas, I., and Bonani, G.: A pervasive millennial-scale cycle in North Atlantic Holocene and glacial climates, 1257-1266, 1997c. 288, 290, 297

Bond, G., Kromer, B., Beer, J., Muscheler, R., Evans, M. N., Showers, W., Hoffmann, S., LottiBond, R., Hajdas, I., and Bonani, G.: Persistent Solar Influence on North Atlantic Climate 15 During the Holocene, 2130-2136, 2001a. 298, 318

Bond, G., Kromer, B., Beer, J., Muscheler, R., Evans, M. N., Showers, W., Hoffmann, S., LottiBond, R., Hajdas, I., and Bonani, G.: Persistent Solar Influence on North Atlantic Climate During the Holocene, Science, 294, 2130-2136, $2001 \mathrm{~b}$.

Bond, G., Kromer, B., Beer, J., Muscheler, R., Evans, M. N., Showers, W., Hoffmann, S., LottiBond, R., Hajdas, I., and Bonani, G.: Persistent Solar Influence on North Atlantic Climate During the Holocene, 2130-2136, 2001c. 290, 291, 298, 316

Bonnefille, R. and Chalie, F.: Pollen-inferred precipitation time-series from equatorial mountains, Africa, the last $40 \mathrm{kyr} \mathrm{BP}$, Global Planet. Change, 26, 25-50, 2000. 318

Brachfeld, S., Acton, G. D., Guyodo, Y., and Banerjee, S. K.: High-resolution paleomagnetic records from Holocene sediments from the Palmer Deep, Western Antartic Peninsula, Earth and Planet. Sci. Lett., 181, 429-441, 2000. 318

Broecker, W., Peteet, D., and Rind, D.: Does the ocean-atmosphere system have more than one stable mode of operation?, Nature, 315, 21-25, 1985. 298

Camill, P., Umbanhowar, C. E., Teed, R., Geiss, C. E., Aldinger, J., et al.: Late-glacial and Holocene climatic effects on fire and vegetation dynamics at the prairie forest ecotone in south-central Minnesota, J. Ecol., 91, 822-836, 2003. 318

Carcaillet, C., Bergeron, Y., Richard, P., Fréchette, B., Gauthier, S., and Prairie, Y.: Change of fire frequency in the eastern Canadian boreal forests during the Holocene: does vegetation

$5,287-326,2009$

Mid-Holocene climate reorganization

K. W. Wirtz et al.

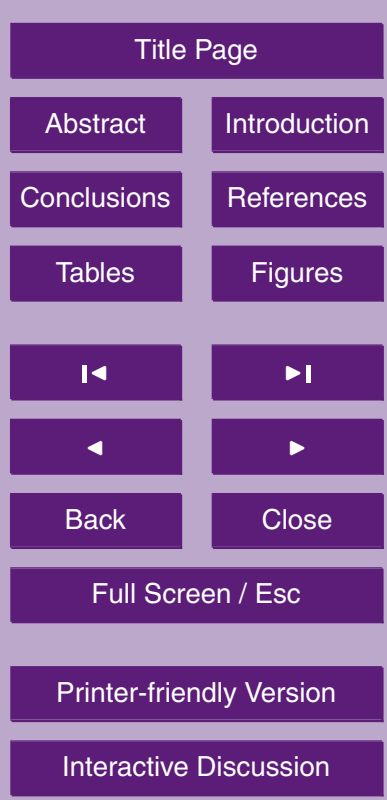


composition or climate trigger the fire regime?, J. Ecol., 89, 930-946, 2001. 318

Chapman, M. R. and Shackleton, N. J.: Evidence of 550-year and 1000-year cyclicities in North Atlantic circulation patterns during the Holocene, Holocene, 10, 287-291, 2000. 318

Claussen, M., Kubatzki, C., Brovkin, V., Ganopolski, A., Hoelzmann, P., and Pachur, H.: Simulation of an abrupt change in Saharan vegetation at the end of the mid-Holocene, Geophys. Res. Lett., 24, 2037-2040, 1999. 289

Clement, A., Seager, R., and Cane, M.: Orbital controls on the El Niño Southern Oscillation and the tropical climate, Paleoceanography, 14, 441-456, 1999. 299

Cook, E., Buckley, B., D'Arrigo, R., and Peterson, M.: Warm-season temperatures since 1600 $B C$ reconstructed from Tasmanian tree rings and their relationship to large-scale sea surface temperature anomalies, Clim. Dynam., 16, 79-91, 2000. 319

Coombes, P. and Barber, K.: Environmental determinism in Holocene research: causality or coincidence?, Area, 37, 303-311, 2005. 289

Cruz, F., Burns, S., Karmann, I., Sharp, W., Vuille, M., Cardoso, A., Ferrari, J., Dias, P. S., and Jr., O. V.: Insolation-driven changes in atmospheric circulation over the past 116000 years in subtropical Brazil, Nature, 434, 63-66, 2005. 318

Curtis, J., Brenner, M., and Hodell, D.: Climate change in the Lake Valencia Basin, Venezuela, $\approx 12600$ yr BP to present, Holocene, 9, 609-619, 1999. 318

Curtis, J. H., Brenner, M., Hodell, D. A., Balser, R. A., Islebe, G. A., and Hooghiemstra, H.: A multi-proxy study of Holocene environmental change in Lowlands of Peten, Guatemala, J. Paleolimnol., 19, 139-159, 1998. 318

Davis, B. A. S., Brewer, S., Stevenson, A. C., Guiot, J., and Data Contributors: The temperature of Europe during the Holocene reconstructed from pollen data, Quatern. Sci. Rev., 22, 15971629, 2003a. 318

Davis, B. A. S., Brewer, S., Stevenson, A. C., Guiot, J., and Data Contributors: The temperature of Europe during the Holocene reconstructed from pollen data, Quatern. Sci. Rev., 22, 15971629, 2003b. 321

Davis, O. K.: Rapid Climate Change in Coastal Southern California Inferred from Pollen analysis of San Joaquin Marsh, Quatern. Res., 23, 227-235, 1992. 318

30 Debret, M., Bout-Roumazeilles, V., Grousset, F., Desmet, M., McManus, J. F., Massei, N., Sebag, D., Petit, J.-R., Copard, Y., and Trentesaux, A.: The origin of the 1500-year climate cycles in Holocene North-Atlantic records, Clim. Past, 3, 569-575, 2007, http://www.clim-past.net/3/569/2007/. 290, 298
$5,287-326,2009$

Mid-Holocene climate reorganization

K. W. Wirtz et al.

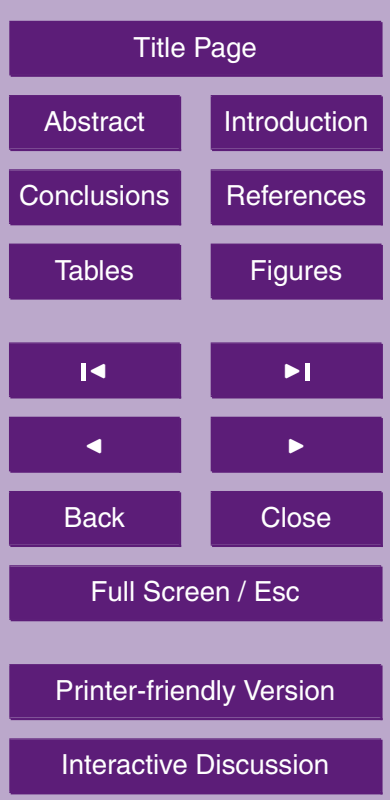


deMenocal, P., Ortiz, J., Guilderson, T., and Sarnthein, M.: Coherent high- and low-latitude climate variability during the Holocene warm period, Science, 288, 2198-2202, 2000a. 318

deMenocal, P., Ortiz, J., Guilderson, T., and Sarnthein, M.: Coherent high- and low-latitude climate variability during the Holocene warm period, Science, 288, 2198-2202, 2000b. 289, 5290

deMenocal, P. B.: Cultural responses to climate change during the late Holocene, Science, 292, 667-673, 2001. 289

Denniston, R., Gonzalez, L., Baker, R.G.and Reagan, M., Asmerom, Y., Edwards, R., and Alexander, E.: Speleothem evidence for Holocene fluctuations of the prairie-forest ecotone, 10 north-central USA, Holocene, 9, 671-676(6), 1999. 318

Diamond, J.: Guns, germs, and steel: the fates of human societies, W. W. Norten \& Company, 1999. 300

Dima, M. and Lohmann, G.: Conceptual model for millennial climate variability: a possible combined solar-thermohaline circulation origin for the 1500-year cycle, Clim. Dynam., 10,

$15 \quad 301-311,2005.298$

Doose-Rolinski, H., Rogalla, U., Scheeder, G., Lückge, A., and von Rad, U.: High resolution temperature and evaporation changes during the late Holocene in the northeastern Arabian Sea, Palaeooceanography, 16, 358-367, 2001. 319

Dorale, J., Gonzalez, L., Reagan, M., Pickett, D., Murrell, M., and Baker, R.: A high resolution record of Holocene climate change in speleothem calcite from Cold Water Cave, northeast lowa, Science, 258, 1626-1630, 1992. 318

Drysdale, R., Zanchetta, G., Hellstrom, J., Maas, R., Fallick, A., Pickett, M., Cartwright, I., and Piccini, L.: Late Holocene drought responsible for the collapse of Old World civilizations is recorded in an Italian cave flowstone, Geology, 34, 101-104, 2006. 318

Ekdahl, E. J., Fritz, S. C., Baker, P. A., Rigsby, C. A., and Coley, K.: Holocene multidecadalto millennial-scale hydrologic variability on the South American Altiplano, The Holocene, 18, 867-876, 2005. 299

Erickson, C. L.: Neo-environmental determinism and agrarian "collapse" in Andean prehistory, Antiquity, 73, 634-642, 1999. 289

30 Fagan, B.: Floods, Famines, And Emperors: El Nino And The Fate Of Civilizations, Basic Books, University of California, Santa Barbara, 1999. 289

Fairbridge, R. and Hillaire-Marcel, C.: An 8,000-yr palaeoclimatic record of the "Double-Hale" 45-yr solar cycle, Nature, 268, 413-416, 1977. 288, 290

Mid-Holocene climate reorganization

K. W. Wirtz et al.

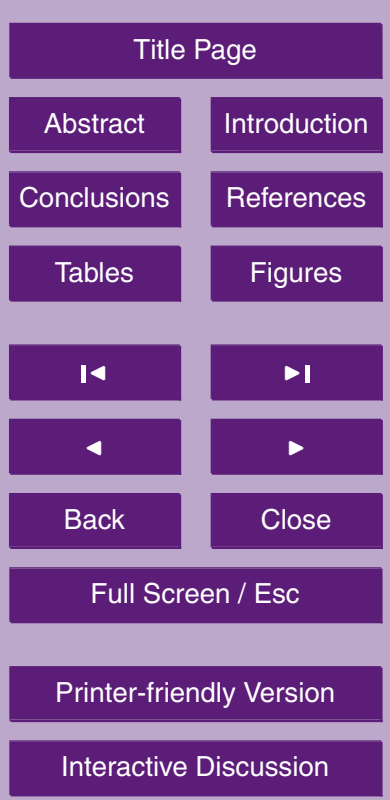


Fengming, C., Tiegang, L., Lihua, Z., and Jun, Y.: A Holocene paleotemperature record based on radiolaria from the northern Okinawa Trough (East China Sea), Quat. Int., 183, 115-122, 2008. 319

Finkel, R. and Nishiizumi, K.: Beryllium 10 concentrations in the Greenland Ice Sheet Project 2 ice core from 3-40 ka, J. Geophys. Res., 102, 26 699-26 706, 1997. 318

Fleitmann, D., Burns, S. J., Mudelsee, M., Neff, U., Kramers, J., Mangini, A., and Matter, A.: Holocene Forcing of the Indian Monsoon Recorded in a Stalagmite from Southern Oman, Science, 300, 1737-1739, 2003. 319

Fleitmann, D., Burns, S., Mangini, A., Mudelsee, M., Kramers, J., Villa, I., Neff, U., Al-Subbary, A., Buettner, A., Hippler, D., et al.: Holocene ITCZ and Indian monsoon dynamics recorded in stalagmites from Oman and Yemen (Socotra), Quaternary Science Reviews, 26, 170-188, 2007. 319

Fontes, J.-C., Gasse, F., and Gibert, E.: Holocene environmental changes in Lake Bangong basin (Western Tibet). Part 1: Chronology and stable isotopes of carbonates of a Holocene lacustrine core, Paleogeogr. Palaeoclimatol. Palaeoecol., 120, 25-47, 1996. 319

Freudenthal, T., Meggers, H., Henderiks, J., Kuhlmann, H., Moreno, A., and Wefer, G.: Upwelling intensity and filament activity off Morocco during the last 250,000 years, Deep-Sea Res. II, 49, 3655-3674, 2002. 318

Gasse, F.: Hydrological changes in the African tropics since the Last Glacial Maximium, Quat. Sci. Revi., 19, 189-211, 2000. 319

Gasse, F.: Diatom-inferred salinity and carbonate oxygen isotopes in Holocene waterbodies of the western Sahara and Sahel (Africa), Quatern. Sci. Rev., 21, 737-767, 2002. 318

Grootes, P. and Stuiver, M.: Oxygen 18/16 variability in Greenland snow and ice with $10^{-3}$ - to $10^{5}$-year time resolution, J. Geophys. Res., 102, $26455-26470,1997.318$

25 Grootes, P. M., Steig, E. J., Stuiver, M., Waddington, E. D., and Morse, D. L.: A new ice core record from Taylor Dome, Antarctica, Eos, 75, p. 225, 1994. 319

Gupta, A., Anderson, D., and Overpeck, J.: Abrupt changes in the Asian southwest monsoon during the Holocene and their links to the North Atlantic Ocean, Nature, 421, 354-356, 2003. 318,319

30 Hantemirov, R. M. and Shiyatov, S. G.: A continuous multi-millennial ring-width chronology in Yamal, northwestern Siberia, Holocene, 12, 717-726, 2002. 319

Haug, G. H., Hughen, K. A., Sigman, D. M., Peterson, L. C., and Röhl, U.: Southward migration of the intertropical convergence zone through the Holocene, Science, 293, 1304, 2001. 299,

Mid-Holocene climate reorganization

K. W. Wirtz et al.
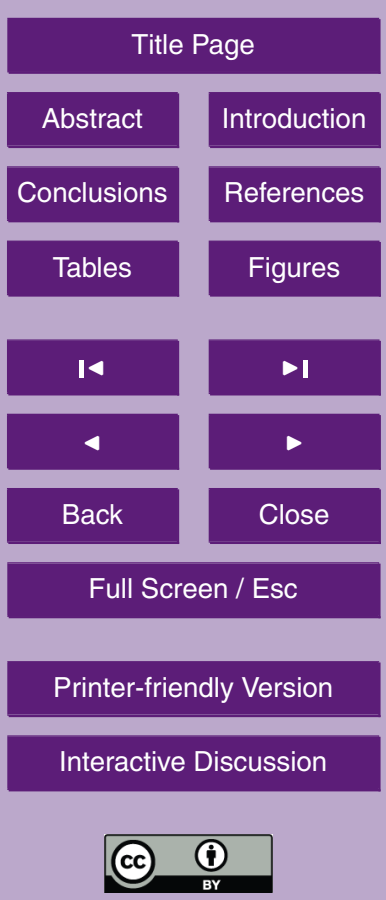
Herzschuh, U., Tarasov, P., Wünnemann, B., and Hartmann, K.: Holocene vegetation and climate of the Alashan Plateau, NW China, reconstructed from pollen data, Paleogeogr. Palaeoclimatol. Palaeoecol., 211, 1-17, 2004. 319

5 Higuera-Gundy, A., Brenner, M., Hodell, D. A., Curtis, J. H., Leyden, B. W., and Binford, M. W.: A $10300{ }^{14} \mathrm{C}$ yr record of climate and vegetation change from Haiti, Quat. Res., 52, 159-170, 1999. 318

Hodell, D., Curtis, J. H., and Brenner, M.: Possible role of climate in the collapse of the Classic Maya Civilization, Nature, 375, 391-394, 1995. 318

10 Hodell, D., Curtis, J., Sierro, F., and Raymo, M.: Correlation of late Miocene to early Pliocene sequences between the Mediterranean and North Atlantic, Paleoceanography, 16, 164-178, 2001a. 318

Hodell, D., Kanfoush, S., Shemesh, A., Crosta, X., Charles, C., and Guilderson, T.: Abrupt Cooling of Antarctic Surface Waters and Sea Ice Expansion in the South Atlantic Sector of the Southern Ocean at 5000 cal yr B.P., Quatern. Res., 56, 191-198, 2001b. 318

Hodell, D. A., Brenner, M., Curtis, J. H., and Guilderson, T.: Solar Forcing of Drought Frequency in the Maya Lowlands, Science, 292, 1367-1370, 2001c. 290, 298

Holmgren, K., Lee-Thorp, J., Cooper, G., Lundblad, K., Partridge, T., Scott, L., Sithaldeen, R., Talma, A., and Tyson, P.: Persistent Millennial-Scale Climatic Variability Over the Past 25 20 thousand Years in Southern Africa, Quatern. Sci. Rev., 22, 2311-2326, 2003. 318

Hu, F. S., Ito, E., Brubaker, L. B., and Anderson, P. M.: Ostracode Geochemical Record of Holocene Climatic Change and Implications for Vegetational Response in the Northwestern Alaska Range, Quatern. Res., 49, 86-95, 1998. 318

Huang, C.-Y., Liew, P.-M., Zhao, M., Chang, T.-C., Kuo, C.-M., Chen, M.-T., Wang, C.-H., and Zheng, L.-F.: Deep sea and lake records of the Southeast Asian paleomonsoons for the last 25 thousand years, Earth and Planet. Sci. Lett., 146, 59-72, 1997. 319

Hughes, M. K. and Graumlich, L. J.: Climatic variations and forcing mechanisms of the last 2000 years. Multi-millenial dendroclimatic studies from the western United States, NATO ASI Series, 141, 109-124, 1996. 318

30 Husum, K. and Hald, M.: A continuous marine record 8000-1600 cal. yr BP from the Malangenfjord, north Norway: foraminiferal and isotopic evidence, The Holocene, 14, 877-887, 2004. 318

Jin, Z., Wu, J., Cao, J., Wang, S., Shen, J., Gao, N., and Zou, C.: Holocene chemical weathering
5, 287-326, 2009

Mid-Holocene climate reorganization

K. W. Wirtz et al.

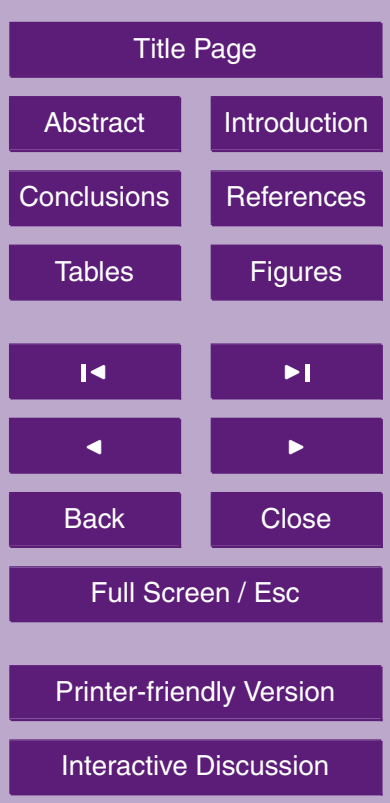


and climatic oscillations in north China: evidence from lacustrine sediments, Boreas, 33, 260-266, 2004. 319

Johnson, T. C., Brown, E. T., McManus, J., Barry, S., Barker, P., and Gasse, F.: A HighResolution Paleoclimate Record Spanning the Past 25, 000 Years in Southern East Africa, $5 \quad$ Science, 296, 113-132, 2002. 318

Jones, V. J., Leng, M. J., Solovieva, N., Sloaneb, H. J., and Tarasovc, P.: Holocene climate of the Kola Peninsula; evidence from the oxygen isotope record of diatom silica, Quatern. Sci. Rev., 23, 833-839, 2004. 318

Jung, S., Davies, G., Ganssen, G., and Kroon, D.: Synchronous Holocene sea surface temperature and rainfall variations in the Asian monsoon system, Quatern. Sci. Rev., 23, 22072218, 2004. 319

Keigwin, L. D.: The little Ice Age and medieval warm period in the Sargasso Sea, Science, 274, 1503-1508, 1996. 318

Kienast, M., Calvert, S. E., Pelejero, C., and Grimalt, J. O.: A critical review of marine sedimen15 tary $\delta{ }^{13}$ Corg-pCO 2 estimates: New palaeorecords from the South China Sea and a revisit of other low-latitude $\delta{ }^{13} \mathrm{C}$ org- $\mathrm{pCO}_{2}$ records, Global Biogeochem. Cy., 15, 113-127, 2001. 319

Kim, J., Meggers, H., Rimbu, N., Lohmann, G., Freudenthal, T., Muller, P., and Schneider, R.: Impacts of the North Atlantic gyre circulation on Holocene climate off northwest Africa, Geology, 35, 387-390, 2007. 289, 298

$20 \mathrm{Kim}, \mathrm{J} . \mathrm{-H}$. and Schneider, R. R.: Low-latitude control of interhemispheric sea-surface temperature contrast in the tropical Atlantic over the past 21 kyears: the possible role of SE trade winds, Clim. Dynam., 21, 337-347, 2003. 318

Knaack, J.: Eine neue Transferfunktion zur Rekonstruktion der Paläoproduktivität aus Gemeinschaften mariner Diatomeen, Berichte Rep. Geol. Paläontologisches Inst. Univ.t Kiel, 83, $25 \quad 1-118,1997.318$

Koutavas, A., Lynch-Stieglitz, J., Marchitto, T., and Sachs, J.: El Niño-Like Pattern in Ice Age Tropical Pacific Sea Surface Temperature, Science, 297, 226-230, 2002. 299

Kropelin, S., Verschuren, D., Lezine, A., Eggermont, H., Cocquyt, C., Francus, P., Cazet, J., Fagot, M., Rumes, B., Russell, J., et al.: Climate-Driven Ecosystem Succession in the Sahara: The Past 6000 Years, Science, 320, 765-768, 2008. 299

Lachniet, M., Asmerom, Y., Burns, S., Patterson, W., Polyak, V., and Seltzer, G.: Tropical response to the $8200 \mathrm{yr}$ B.P. cold event? Speleothem isotopes indicate a weakened early Holocene monsoon in Costa Rica, Geology, 32, 957-960, 2004. 318

5, 287-326, 2009

Mid-Holocene climate reorganization

K. W. Wirtz et al.

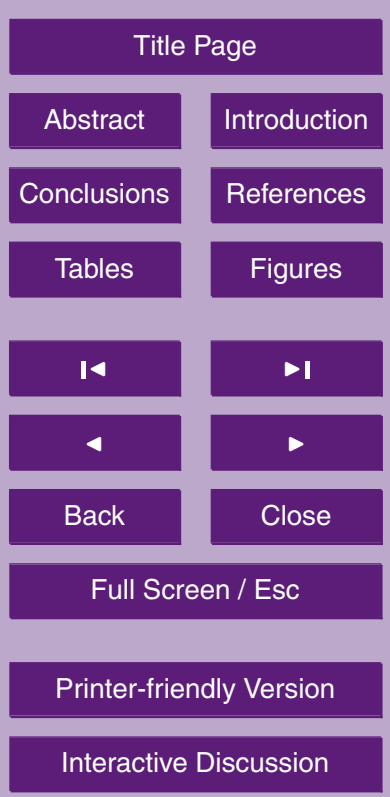


Laird, K. R., Fritz, S. C., Maasch, K. A., and Cumming, B. F.: Greater drought intensity and frequency before A.D. 1200 in the northern Great Plains, USA, Nature, 384, 552-554, 1996. 318

Lamy, F., Hebbeln, D., Röhl, U., and Wefer, G.: Holocene rainfall variability in southern Chile: 5 a marine record of latitudinal shifts of the Southern Westerlies, Earth and Planet. Sci. Lett., 185, 369-382, 2001. 318

Lamy, F., Rühlemann, C., Hebbeln, D., and Wefer, G.: High- and low-latitude climate control on the position of the southern Peru-Chile Current during the Holocene, Palaeooceanography, 17, 1028, doi:10.1029/2001PA000727, 2002. 318

10 Lea, D., Pak, D., Peterson, L., and Hughen, K.: Synchroneity of tropical and High-Latitude Atlantic Temperatures over the last glacial termination, Science, 301, 1361-1364, 2003. 318

Liu, J., Houyuan, L., Negendank, J., Mingram, J., Xiangjun, L., Wenyuan, W., and Guoqiang, C.: Periodicity of Holocene climatic variations in the Huguangyan Maar Lake, Chinese Sci. Bull., 45, 1712-1718, 2000a. 319

Liu, Z., Kutzbach, J., and Wu, L.: Modeling climate shift of El Nino variability in the Holocene., Geophys. Res. Lett., 27, 2265-2268, 2000b.

Lohmann, G. and Lorenz, S. J.: Orbital forcing on atmospheric dynamics during the last interglacial and glacial inception, in: The climate of past interglacials, edited by Sirocko, F., Claussen, M., Sanchez-Goni, M. F., and Litt, T., vol. 7 of Developments in Paleoenvironmen20 tal Research, Elsevier, 2007. 299

Lorenz, S. and Lohmann, G.: Acceleration technique for Milankovitch type forcing in a coupled atmosphere-ocean circulation model: method and application for the Holocene, Climate Dynam., 23, 727-743, 2004. 299

Lorenz, S., Kim, J., Rimbu, N., Schneider, R., and Lohmann, G.: Orbitally driven insolation forcing on Holocene climate trends: Evidence from alkenone data and climate modeling, Palaeooceanography, 21, PA1002, doi:10.1029/2005PA001152, 2006. 298

Loubere, P., Richaud, M., Liu, Z., and Mekik, F.: Oceanic conditions in the eastern equatorial Pacific during the onset of ENSO in the Holocene, Quat. Res., 60, 142-148, 2003. 299

Marchal, O., Cacho, I., Stocker, T., Grimalt, J., Calvo, E., Martrat, B., Shackleton, N., Vautravers, 30 M., Cortijo, E., van Kreveld, S., et al.: Apparent long-term cooling of the sea surface in the northeast Atlantic and Mediterranean during the Holocene, Quatern. Sci. Rev., 21, 455-483, 2002. 298

Masson, V., Vimeux, F., Jouzel, J., Morgan, V., Delmotte, M., et al.: Holocene climate variability

Mid-Holocene climate reorganization

K. W. Wirtz et al.

Title Page

Abstract

Conclusions

Tables

\section{Figures}

1

14

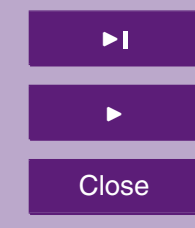

Full Screen / Esc

Printer-friendly Version

Interactive Discussion 
in Antarctica based on 11 ice-core isotopic records, Quatern. Res., 54, 348-358, 2000. 319 Mayewski, P., Rohling, E., Stager, J., Karlen, W., Maasch, K., Meeker, L., Meyerson, E., Gasse, F., Kreveld, S., Holmgren, K., et al.: Holocene climate variability, Quatern. Res., 62, 243-255, 2004. 288, 289, 290, 291

5 McDermott, F.: Palaeo-climate reconstruction from stable isotope variations in speleothems: a review, Quatern. Sci. Rev., 23, 901-918, 2004. 318

McDermott, F., Mattey, D., and Hawkesworth, C.: Centennial-scale Holocene climate variability revealed by a high-resolution speleothem $\delta^{18} \mathrm{O}$ record from S.W. Ireland, Science, 294, 1328-1331, 2001. 290

10 Mikolajewicz, U. and Maier-Reimer, E.: Internal secular variability in an ocean general circulation model, Clim. Dynam., 4, 145-156, 1990. 300

Moberg, A., Sonechkin, D., Holmgren, K., Datsenko, N., and Karlin, W.: Highly variable Northern Hemisphere temperatures reconstructed from low- and high-resolution proxy data, Nature, 433, 613-617, 2005. 289, 290, 292

Morrill, C., Overpeck, J., and Cole, J.: A synthesis of abrupt changes in the Asian summer monsoon since the last deglaciation, The Holocene, 13, 465-476, 2003. 290, 292, 297

Moy, C., Seltzer, G. O., Rodbell, D. T., and Anderson, D. M.: Variability of El Niño/Southern Oscillation activity at millennial timescales during the Holocene epoch, Nature, 420, 162165, 2002. 292, 296, 299, 318

20 Noren, A., Bierman, P., Steig, E., Lini, A., and Southon, J.: Millennial-scale Storminess Variability in the Northeastern United States during the Holocene Epoch, 821-824, 2002a. 318

Noren, A., Bierman, P., Steig, E., Lini, A., and Southon, J.: Millennial-scale Storminess Variability in the Northeastern United States during the Holocene Epoch, Nature, 419, 821-824, 2002b. 290, 316

Oba, T. and Murayama, M.: Sea-surface temperature and salinity changes in the northwest Pacific since the Last Glacial Maximum, J. Quat. Sci., 19, 335-346, 2004. 318

O'Brien, S. R., Mayewski, P. A., Meeker, L. D., Meese, D. A., Twickler, M. S., and Whitlow, S. I.: Complexity of Holocene Climate as Reconstructed from a Greenland Ice Core, Science, 270, 1962-1964, 1995. 296

30 Petit, J. R., Jouzel, J., Raynaud, D., Barkov, N. I., Barnola, J.-M., et al.: Climate and atmospheric history of the past 420, 000 years from the Vostok ice core, Antarctica, Nature, 399, 429-436, 1999. 319

Renssen, H., Goosse, H., Fichefet, T., and Campin, J.: The 8.2 kyr BP event simulated by a

Mid-Holocene climate reorganization

K. W. Wirtz et al.
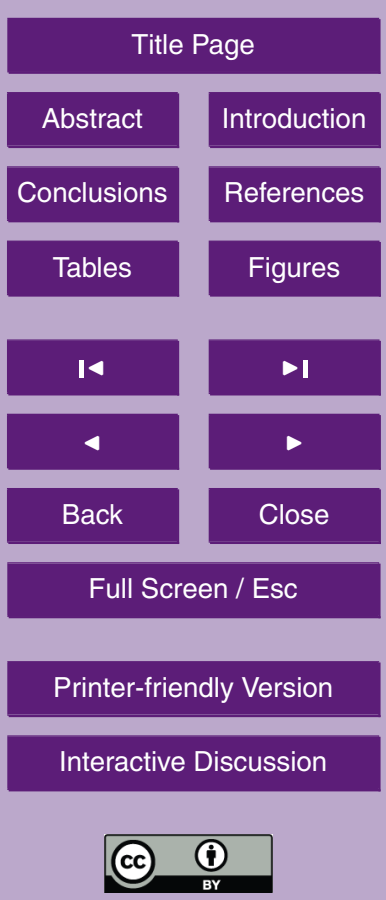
global atmosphere sea-ice ocean model., Geophys. Res. Lett., 28, 1567-1570, 2001. 289

Renssen, H., Goosse, H., and Muscheler, R.: Coupled climate model simulation of Holocene cooling events: oceanic feedback amplifies solar forcing, Clim. Past, 2, 79-90, 2006, http://www.clim-past.net/2/79/2006/. 298

5 Richerson, P. J., Boyd, R., and Bettinger, R. L.: Was agriculture impossible during the Pleistocene but mandatory during the Holocene? A Climate Change Hypothesis, Archaeol. Austriaca, 66, 1-50, 2001. 288

Ricketts, R. D., Johnson, T. C., Brown, E. T., Rasmussen, K. A., and Romanovsky, V. V.: The Holocene paleolimnology of Lake Issyk-Kul, Kyrgyzstan: trace element and stable isotope composition of ostracodes, Palaeogeogr., Palaeoclimatol., Palaeoecol., 176, 207-227, 2001. 316,319

Rimbu, N., Lohmann, G., Lorenz, S., Kim, J., and Schneider, R.: Holocene climate variability as derived from alkenone sea surface temperature and coupled ocean-atmosphere model experiments, Climate Dynam., 23, 215-227, 2004. 289, 296, 298, 299

15 Rodbell, D., Seltzer, G. O., Anderson, D., Abbott, M., Enfield, D., and Newman, J.: An 15000Year Record of El-Niño Alluviation in Southwestern Ecuador, Science, 283, 516-520, 1999. 299, 318

Rosenthal, Y., Oppo, D. W., and Linsley, B. K.: The amplitude and phasing of climate change during the last deglaciation in the Sulu Sea, western equatorial Pacific, Geophys. Res. Lett., 30, 1428, doi:10.1029/2002GL016612, 2003. 318, 319

Rubensdotter, L. and Rosqvist, G.: The effect of geomorphological setting on Holocene lake sediment variability, northern Swedish Lapland, J. Quat. Sci., 18, 757-767, 2003. 318

Rühlemann, C., Mulitza, S., Lohmann, G., Paul, A., Prange, M., and Wefer, G.: Intermediate depth warming in the tropical Atlantic related to weakened thermohaline circulation: Combining paleoclimate data and modeling results for the last deglaciation, Palaeooceanography, 19, 1025-1035, doi:10.1029/2003PA000948, 2004. 298

Sarkar, A., Ramesh, R., Somayajulu, B., Agnihotri, R., Jull, A., and Burr, G.: High resolution Holocene monsoon record from the eastern Arabian Sea, Earth and Planet. Sci. Lett., 177, 209-218, 2000. 319

30 Sarnthein, M., van Kreveld, S., Erlenkeuser, H., Grootes, P., Kucera, M., Pflaumann, U., and Schulz, M.: Centennial-to-millennial-scale periodicities of Holocene climate and sediment injections off the western Barents shelf, 75N, Boreas, 32, 447-461, 2003a. 318

Sarnthein, M., van Kreveld, S., Erlenkeuser, H., Grootes, P., Kucera, M., Pflaumann, U., and
5, 287-326, 2009

Mid-Holocene climate reorganization

K. W. Wirtz et al.

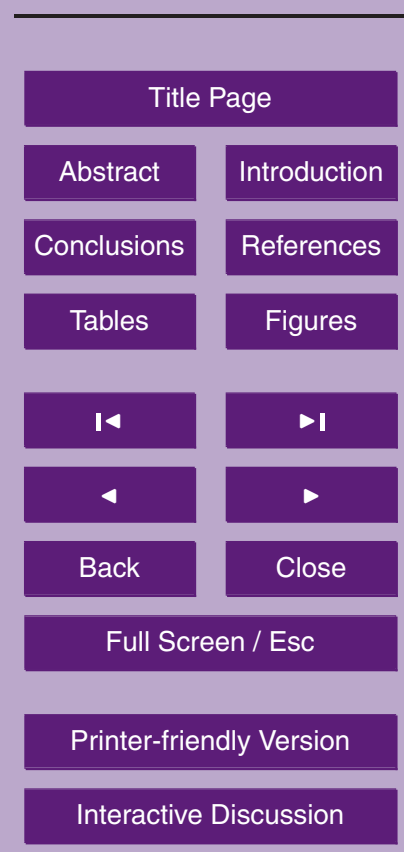


Schulz, M.: Centennial-to-millennial-scale periodicities of Holocene climate and sediment injections off the western Barents shelf, 75N, Boreas, 32, 447-461, 2003b. 290

Schilman, B., Almogi-Labin, A., and Bar-Matthews, M.: Late Holocene productivity and hydrographic variability in the eastern Mediterranean inferred from benthic foraminiferal stable isotopes, Palaeooceanography, 18, 1064-1076, 2003. 318

Schulz, H.: Meeresoberflächentemperaturen vor 10:000 Jahren - Auswirkungen des frühholozänen Insolationsmaximums, Berichte-reports, Geologisch-Paläontologischen Institut und Museum, Christian-Albrechts-Universität, Kiel, 1995. 319

Schulz, M. and Mudelsee, M.: REDFIT: Estimating red-noise spectra directly from unevenly spaced paleoclimatic time series, Computers \& Geosciences, 28, 421-426, 2002. 292

Schulz, M. and Paul, A.: Holocene Climate Variability on Centennial-to-Millennial Time Scales: 1. Climate Records from the North-Atlantic Realm, in: Climate Development and History of the North Atlantic Realm, edited by: Wefer, G., Berger, W., Behre, K., and Jansen, E., 41-54, Springer, Berlin, 2002. 296, 298

15 Seeberg-Elverfeldt, I. A., Lange, C. B., Arz, H. W., Pätzold, J., and Pike, J.: The significance of diatoms in the formation of laminated sediments of the Shaban Deep, Northern Red Sea, Mar. Geol., 209, 279-301, 2004. 318

Seppä, H., Birks, H. J. B., Giesecke, T., Hammarlund, D., Alenius, T., Antonsson, K., Bjune, A. E., Heikkilä, M., MacDonald, G. M., Ojala, A. E. K., Telford, R. J., and Veski, S.: Spatial structure of the $8200 \mathrm{cal}$ yr BP event in northern Europe, Clim. Past, 3, 225-236, 2007, http://www.clim-past.net/3/225/2007/. 290

Shimada, C., Ikehara, K., Tanimura, Y., and Hasegawa, S.: Millennial-scale variability of Holocene hydrography in the southwestern Okhotsk Sea: diatom evidence, Holocene, 14, 641-650, 2004. 319

Simmonds, I. and Walland, D. J.: Decadal and centennial variability of the southern semiannual oscillation simulated in the GFDL coupled GCM, Clim. Dynam., 14, 45-53, 1998. 299

Sirocko, F.: What Drove Past Teleconnections?, Science, 301, 1336-1337 doi:10.1126/science.1088626, 2003. 289

Solanki, S. K., Usoskin, I. G., Kromer, B., Schüssler, M., and Beer, J.: Unusual activity of the Sun during recent decades compared to the previous 11000 years, Nature, 431, 1084, doi:10.1038/nature02995, 2004. 318

Sperling, M., Schmiedl, G., Hemleben, C., Emeis, K. C., Erlenkeuser, H., and Grootes, P. M.: Black Sea impact on the formation of eastern Mediterranean sapropel S1? Evidence from
5, 287-326, 2009

Mid-Holocene climate reorganization

K. W. Wirtz et al.

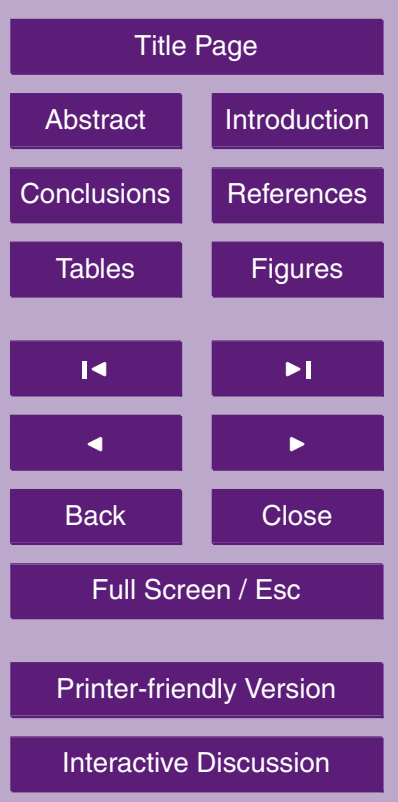


the Marmara Sea, Science, 190, 9-21, 2003. 318

Stager, J., Cumming, B., and Meeker, L.: A 10000 year high-resolution diatom record from Pilkington Bay, Lake Victoria, East Africa, Quatern. Res., 59, 172-181, 2003. 318

Stanley, S. and Deckker, P. D.: A Holocene record of allochthonous, aeolian mineral grains in an Australian alpine lake; implications for the history of climate change in southeastern Australia, J. Paleolimnology, 27, 207-219, 2002a. 319

Stanley, S. and Deckker, P. D.: A Holocene record of allochthonous, aeolian mineral grains in an Australian alpine lake; implications for the history of climate change in southeastern Australia, J. Paleolimnol., 27, 207-219, 2002b. 316

10 Steig, E. J.: Mid-Holocene Climate Change, Science, 286, 1485-1487, 1999. 289, 292

Steig, E. J., Brook, E. J., White, J. W. C., Sucher, C. M., Bender, M. L., Lehman, S. J., Morse, D. L., Waddington, E. D., and Clow, G. D.: Synchronous Climate Changes in Antarctica and the North Atlantic, Science, 282, 92, doi:10.1126/sience.282.5386.92, 1998. 319

Stocker, T., Wright, D., and Broecker, W.: The influence of high-latitude surface forcing on the global thermohaline circulation, Paleoceanography, 7, 529-541, 1992. 298

Stott, L., Cannariato, K., Thunell, R., Haug, G. H., Koutavas, A., and Lund, S.: Decline of surface temperature and salinity in the western tropical Pacific Ocean in the Holocene epoch, Nature, 431, 56-59, 2004. 319

Stuiver, M., Reimer, P. J., Bard, E., Beck, J. W., Burr, G. S., Hughen, K. A., Kromer, B., McCormac, G., van der Plicht, J., and Spurk, M.: INTCAL98 radiocarbon age calibration, $24000-$ 0 cal BP, Radiocarbon, 40, 1041-1083, 1998. 318

Sun, Y., Oppo, D., Xiang, R., Liu, W., and Gao, S.: Last deglaciation in the Okinawa Trough: Subtropical northwest Pacific link to Northern Hemisphere and tropical climate, Palaeooceanography, 20, 4005, doi:10.1029/2004PA001061, 2005. 319

Te Raa, L. and Dijkstra, H.: Modes of internal thermohaline variability in a single-hemispheric ocean basin, J. Mar. Res., 61, 491-516, 2003. 296, 300

Thompson, L. G., Mosley-Thompson, E., Davis, M. E., Henderson, K. A., Brecher, H. H., Zagorodnov, V. S., Mashiotta, T. A., Lin, P.-N., Mikhalenko, V. N., Hardy, D. R., and Beer, J.: Kilimanjaro ice core records: Evidence of Holocene climate change in tropical Africa, $30 \quad$ Science, 298, 589-593, 2002. 319

Thompson, L. G., Mosley-Thompson, E., Davis, M., Henderson, P.-N. L. K., Mashiotta, T. A., et al.: Tropical glacier and ice core evidence of climate change on annual to millennial time scales, Clim. Change, 59, 137-155, 2003a. 318

$5,287-326,2009$

Mid-Holocene climate reorganization

K. W. Wirtz et al.

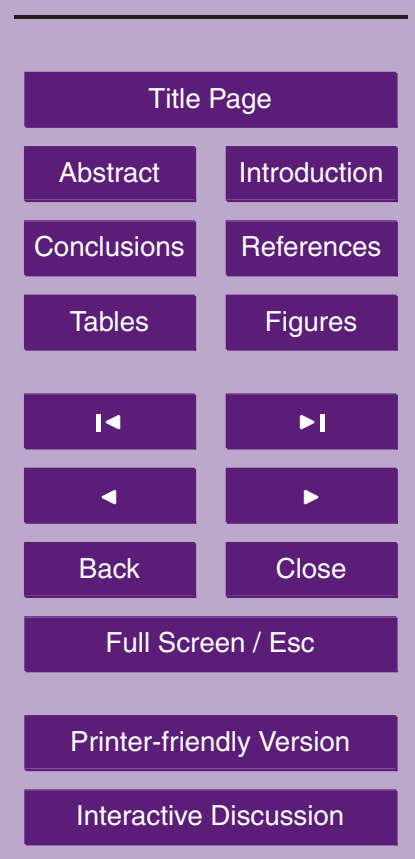


Thompson, L. G., Mosley-Thompson, E., Davis, M., Henderson, P.-N. L. K., Mashiotta, T. A., et al.: Tropical glacier and ice core evidence of climate change on annual to millennial time scales, Clim. Change, 59, 137-155, 2003b. 290, 321

Thomson, D.: Time Series Analysis of Holocene Climate Data, Philosophical Transactions of the Royal Society of London. Series A, Mathematical and Physical Sciences (1934-1990), 330, 601-616, 1990. 292

von Grafenstein, U., Erlenkeuser, H., Müller, J., Jouzel, J., and Johnsen, S.: The cold event 8200 years ago documented in oxygen isotope records of precipitation in Europe and Greenland, Clim. Dynam., 14, 73-81, 1998. 318

10 von Storch, H., Zorita, E., Jones, J. M., Dimitriev, Y., Gonzalez-Rouco, F., and Tett, S. F. B.: Reconstructing Past Climate from Noisy Data, Science, 306, 679-682, 2004. 289

Wang, E. A.: Millennial reoccurrence of century-scale abrupt events of East Asian Monsoon: a possible heat conveyor for the global deglaciation, Palaeooceanography, 14, 725-731, 1999. 319

15 Wang, L., Sarnthein, M., Erlenkeuser, H., Grimalt, J., Grootes, P., Heilig, S., Ivanova, E., Kienast, M., Pelejero, C., and Pflaumann, U.: East Asian monsoon climate during the late Pleistocene: high-resolution sediment records from the South China Sea, Mar. Geol., 156, 245284, 1999. 319

Wang, Y., Cheng, H., Edwards, R., He, Y., Kong, X., An, Z., Wu, J., Kelly, M., Dykoski, C., and $\mathrm{Li}, \mathrm{X}$.: The holocene asian monsoon: Links to solar changes and north Atlantic climate, Science, 308, 854-857, 2005. 319

Weber, S. L., Crowley, T. J., and van der Schrier, G.: Solar irradiance forcing of centennial climate variability during the Holocene, Clim. Dynam., 22, 539-553, 2004. 296, 300

Weijer, W. and Dijkstra, H.: Multiple oscillatory modes of the global ocean circulation, J. Phys. Oceanography, 33, 2197-2213, 2003. 296, 298, 300

Wick, L., Lemcke, G., and Sturm, M.: Evidence of lateglacial and Holocene climatic change and human impact in eastern Anatolia: high-resolution pollen, charcoal, isotopic and geochemical records from the laminated sediments of Lake Van, Turkey, 665-675, 2003a. 318

Wick, L., Lemcke, G., and Sturm, M.: Evidence of lateglacial and Holocene climatic change and human impact in eastern Anatolia: high-resolution pollen, charcoal, isotopic and geochemical records from the laminated sediments of Lake Van, Turkey, The Holocene, 13, 665-675, 2003b. 316

Wirtz, K. and Lemmen, C.: A Global Dynamic Model for the Neolithic Transition, Clim. Change,

Mid-Holocene climate reorganization

K. W. Wirtz et al.

Title Page

Abstract

Conclusions

Tables

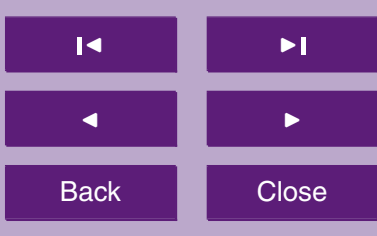

Full Screen / Esc

Printer-friendly Version

Interactive Discussion 
59, 333-367, 2003. 301

Xiao, J., Nakamura, T., Lu, H., and Zhang, G.: Holocene climate changes over the desert/loess transition of north-central China, Earth and Planet. Sci. Lett., 197, 11-18, 2002. 319

Yu, Z., Vitt, D., Campbell, I., and Apps, M.: Understanding Holocene peat accumulation pattern of continental fens in western Canada, Can. J. Bot., 81, 267-282, 2003. 318

Yuan, D., Cheng, H., Edwards, R. L., Dykoski, C. A., Kelly, M. J., Zhang, M., et al.: Timing, duration, and transitions of the last interglacial Aasian monsoon, Science, 304, 575, doi:10.1126/sience.1091220, 2004. 319

Zhang, M., Yuan, D., Lin, Y., Qin, J., Bin, L., Cheng, H., and Edwards, R. L.: A 6000-year highresolution climatic record from a stalagmite in Xiangshui Cave, Guilin, China, Holocene, 14, 697-702, 2004. 319

\section{5, 287-326, 2009}

Mid-Holocene climate reorganization

K. W. Wirtz et al.

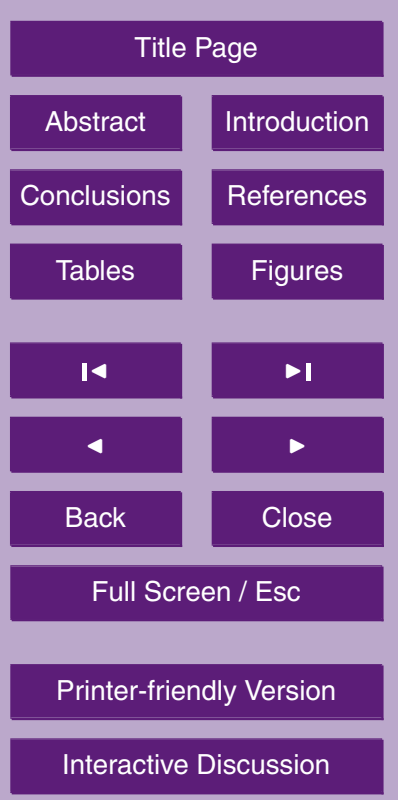


Table 1. Proxy variables used in this study.

\begin{tabular}{l}
\hline Proxy type \\
\hline Isotopic oxygen fractionation \\
$\delta^{18} \mathrm{O}$
\end{tabular}

Lithic composition

$\mathrm{Mg} / \mathrm{Ca}$, Charcoal, Clay, Bulk dens., Lightness, Grayscale, HSG, Lithic grains, GSD, LOI

\section{Description}

The interpretation of isotopic fractionation of oxygen $\left(\delta^{18} \mathrm{O}\right)$ highly depends on geographic location, environmental setting, and type of record. $\delta^{18} \mathrm{O}$ variations in Andean glaciers and polar ice caps represent temperature. Measured in biologic deposits from closed water bodies, $\delta^{18} \mathrm{O}$ usually indicates changes in the water balance, and thus effective moisture. However, the signal cannot be separated from temperature effects during times when the lake system is open. Speleothem $\delta^{18} \mathrm{O}$ records the amount and composition of cave water, mostly during the wet season, and may also be influenced by temperature and above-cave lithology.

The ratio between $\mathrm{Mg}$ and Ca relates to salinity (from calcium precipitation and $\mathrm{Mg}$ dissolution) or inorganic material input (magnesium from weathering). Wick et al. (2003b) interpret the variable $\mathrm{Mg}$ at constant $\mathrm{Ca}$ in a closed lake as changes in effective moisture, similar to the $\mathrm{Sr} / \mathrm{Ca}$ ratio in ostracod shells (Ricketts et al., 2001). Grayscale density (GSD) and loss on ignition (LOI) quantify the inflow of inorganic versus organic matter. From this, cold/humid and warm/dry climates can identified but the temperature signal not separated from precipitation. The shape of grains indicates the transport process: rounded quartz grains with frequent silica coating point to aeolian import pointing to dry phases in the origin region (Stanley and Deckker, 2002b). Coarse sediment layer with low organic content and many terrestrial plant macrofossils have been used by Noren et al. (2002b) to find exceptional runoff events and thus storminess. Occurence of allochtonous hematite-stained grains (HSG) and icelandic glass points to ice-rafting as a consequence of increased glacier calving (e.g. Bond et al., 2001c); The preservation status of aragonite at intermediate measures the bottom-water corrosiveness, and is therefore indicative for changes in the THC.
$5,287-326,2009$

Mid-Holocene climate reorganization

K. W. Wirtz et al.

\begin{tabular}{|c|c|}
\hline \multicolumn{2}{|c|}{ Title Page } \\
\hline Abstract & Introduction \\
\hline Conclusions & References \\
\hline Tables & Figures \\
\hline I & \\
\hline 4 & $-\mathbf{I}$ \\
\hline Back & Close \\
\hline Full Screen / Esc \\
\hline Printer-friendly Version
\end{tabular}


Mid-Holocene climate reorganization

K. W. Wirtz et al.

Table 1. Continued.

\begin{tabular}{ll}
\hline Proxy type & Description \\
\hline Species composition & Relative abundance of algal species is related to stratification \\
Pollen, Radiolaria, \% Diatoms & and mixed layer depth and, thus, to the factor controlling both \\
& variables such as trade wind strength or freshwater increase. \\
& Pollen spectra are often taken to infer precipitation anomalies \\
& (as shaping the community structure within forests). \\
\hline
\end{tabular}

Title Page

\begin{tabular}{c|c}
\hline Abstract & Introduction \\
\hline Conclusions & References \\
\hline Tables & Figures \\
\hline I4 & - I \\
\hline 4 & - \\
\hline Back & Close \\
\hline Full Screen / Esc \\
\hline Printer-friendly Version \\
\hline Interactive Discussion
\end{tabular}


Table 2. Location, type, temporal coverage and reference of the climate proxy time series used in this study; the numbers in the table identify the position of proxy sites in the map (Fig. 1). Abbreviations: $S S=$ sea surface, $T=$ temperature, $S=$ salinity, $P=$ precipitation, $L G=$ lithic grains, $\mathrm{SSN}=$ sun spot number, Lk=Lake, Cv=Cave.

\begin{tabular}{|c|c|c|c|c|c|c|c|c|c|}
\hline No & Site & Proxy & Per & Reference & No & Site & Proxy & Per & Reference \\
\hline 1 & NW Alaska & $\mathrm{Mg} / \mathrm{Ca} \mathrm{T}$ & $0-11$ & Hu et al. 1998 & 2 & NW Pacific & $\delta^{18} \mathrm{O}$ & $0-12$ & Oba and Murayama 2004 \\
\hline 3 & Owens Lk, CA & $\delta^{18} \mathrm{O}$ & $0-12$ & Benson et al. 2002 & 4 & E California & $\mathrm{P}$ & $0-8$ & Hughes and Graumlich 1996 \\
\hline 5 & W Canada & Density & $0-8$ & Yu et al. 2003 & 6 & S California & Moisture & $0-7$ & Davis 1992 \\
\hline 7 & Moon Lk, ND & Salinity & $0-11$ & Laird et al. 1996 & 8 & Kimble, MN & Charcoal & $0-12$ & Camill et al. 2003 \\
\hline 9 & Sharkey, MN & Charcoal & $0-12$ & Camill et al. 2003 & 10 & NC America & $\delta^{18} \mathrm{O}$ & $0-9$ & Denniston et al. 1999 \\
\hline 11 & Cold Water Cv, IA & $\delta^{18} \mathrm{O}$ & $0-8$ & Dorale et al. 1992 & 12 & Guatemala & $\delta^{18} \mathrm{O}(\mathrm{Cy})$ & $0-8$ & Curtis et al. 1998 \\
\hline 13 & Guatemala & $\delta^{18} \mathrm{O}(\mathrm{Co})$ & $0-10$ & Curtis et al. 1998 & 14 & Guatemala & $\delta^{18} \mathrm{O}(\mathrm{Py})$ & $0-10$ & Curtis et al. 1998 \\
\hline 15 & E Pacific & $\delta^{18} \mathrm{O}$ & $2-12$ & Rosenthal et al. 2003 & 16 & Yucatan & $\delta^{18} \mathrm{O}(\mathrm{Ph})$ & $0-8$ & Hodell et al. 1995 \\
\hline 17 & Yucatan & $\delta^{18} \mathrm{O}(\mathrm{Py})$ & $0-8$ & Hodell et al. 1995 & 18 & Costa Rica & $\delta^{18} \mathrm{O}$ & $5-9$ & Lachniet et al. 2004 \\
\hline 19 & E Canada & Charcoal & $0-7$ & Carcaillet et al. 2001 & 20 & Ecuador & ENSO & $0-10$ & Moy et al. 2002 \\
\hline 21 & E Canada & Charcoal & $0-8$ & Carcaillet et al. 2001 & 22 & Ecuador & GSD & $0-12$ & Rodbell et al. 1999 \\
\hline 23 & Huascaran, Peru & $\delta^{18} \mathrm{O}$ & $0-12$ & Thompson et al. 2003a & 24 & Chile & $\delta^{18} \mathrm{O}$ & $0-8$ & Lamy et al. 2002 \\
\hline 25 & Chilean Coast & SST & $0-8$ & Lamy et al. 2001 & 26 & Haiti & $\delta^{18} \mathrm{O}$ & $0-10$ & Higuera-Gundy et al. 1999 \\
\hline 27 & New England & Storms & $0-12$ & Noren et al. 2002a & 28 & Lk Titikaka & Level & $0-4$ & Abbott et al. 1997 \\
\hline 29 & Sajama, Bolivia & Particles & $0-12$ & Thompson et al. 2003a & 30 & Sajama, Bolivia & $\delta^{18} \mathrm{O}$ & $0-12$ & Thompson et al. 2003a \\
\hline 31 & Venezuela & $\delta^{18} \mathrm{O}$ & $0-8$ & Curtis et al. 1999 & 32 & NE Canada & GSD & $4-9$ & Barber et al. 1999 \\
\hline 33 & W Antarctic & Inclination & $1-9$ & Brachfeld et al. 2000 & 34 & Cariaco Basin & GSD & $0-12$ & Haug et al. 2001 \\
\hline 35 & Cariaco Basin & Titanium & $0-12$ & Haug et al. 2001 & 36 & Cariaco Basin & SST & $0-12$ & Lea et al. 2003 \\
\hline 37 & Bermuda Rise & $\delta^{18} \mathrm{O}$ & $1-10$ & Keigwin 1996 & 38 & Botuvera Cv, Brasil & $\delta^{18} \mathrm{O}$ & $0-12$ & Cruz et al. 2005 \\
\hline 39 & Greenland Ice & $\mathrm{Be}^{10}$ & $3-12$ & Finkel and Nishiizumi 1997 & 40 & Greenland Ice & $\delta^{18} \mathrm{O}$ & $0-10$ & Grootes and Stuiver 1997 \\
\hline 41 & Greenland Ice & SSN & $0-11$ & Solanki et al. 2004 & 42 & Greenland Ice & $\delta^{14} \mathrm{C}$ & $0-12$ & Stuiver et al. 1998 \\
\hline 43 & W Atlantic & $\delta^{18} \mathrm{O}(\mathrm{Tu})$ & $0-11$ & Arz et al. 2001 & 44 & W Atlantic & $\delta^{18} \mathrm{O}$ & $0-11$ & Arz et al. 2001 \\
\hline 45 & Eq Atlantic & $\Delta \mathrm{SST}$ & $0-12$ & Kim and Schneider 2003 & 46 & N Atlantic & HSG & $0-12$ & Gupta et al. 2003 \\
\hline 47 & N Atlantic & LG & $1-12$ & Bond et al. 1997a & 48 & Trop Atlantic & $\delta^{18} \mathrm{O}$ & $0-11$ & Knaack 1997 \\
\hline 49 & Trop Atlantic & SST & $0-12$ & deMenocal et al. 2000a & 50 & N Atlantic & HSG & $0-12$ & Bond et al. 2001a \\
\hline 51 & Canary & $\delta^{18} \mathrm{O}$ & $0-12$ & Freudenthal et al. 2002 & 52 & Ireland & $\delta^{18} \mathrm{O}$ & $0-10$ & McDermott 2004 \\
\hline 53 & NW Morocco & $\delta^{18} \mathrm{O}$ & $5-9$ & Hodell et al. 2001a & 54 & SW Europe & $\Delta \mathrm{T}$ & $0-12$ & Davis et al. 2003a \\
\hline 55 & NW Europe & $\Delta \mathrm{T}$ & $0-12$ & Davis et al. 2003a & 56 & S Atlantic & LG & $0-10$ & Hodell et al. 2001b \\
\hline 57 & Swiss Alpes & $\mathrm{T} 7$ & $0-9$ & Wick et al. 2003a & 58 & Swiss Alpes & $\mathrm{P}$ & $0-9$ & Wick et al. 2003a \\
\hline 59 & Swiss Alpes & $\mathrm{P}$ & $0-8$ & Wick et al. 2003a & 60 & C Italy & $\mathrm{Mg} / \mathrm{Ca} \mathrm{T}$ & $1-7$ & Drysdale et al. 2006 \\
\hline 61 & Angola Basin & $\mathrm{U}_{37}^{k^{\prime}} \mathrm{SST}$ & $0-12$ & Kim and Schneider 2003 & 62 & C Italy & $\delta^{18} \mathrm{O}$ & $1-7$ & Drysdale et al. 2006 \\
\hline 63 & S Germany & $\delta^{18} \mathrm{O}$ & $0-12$ & von Grafenstein et al. 1998 & 64 & Sahel & $\delta^{18} \mathrm{O}$ & $0-12$ & Gasse 2002 \\
\hline 65 & N Atlantic & SST & $1-12$ & Sarnthein et al. 2003a & 66 & N Norway & $\mathrm{T}$ & $1-8$ & Husum and Hald 2004 \\
\hline 67 & Sweden & GSD & $1-11$ & Rubensdotter and Rosqvist 2003 & 68 & N Finland & $\mathrm{T}$ & $1-8$ & Husum and Hald 2004 \\
\hline 69 & N Atlantic & GSD & $1-12$ & Chapman et al. 2000 & 70 & Marmara Sea & $\delta^{18} \mathrm{O}$ & $0-12$ & Sperling et al. 2003 \\
\hline 71 & Marmara Sea & $\mathrm{U}_{37}^{k^{\prime}} \mathrm{SST}$ & $0-12$ & Sperling et al. 2003 & 72 & SE Africa & $\delta^{18} \mathrm{O}$ & $0-10$ & Holmgren et al. 2003 \\
\hline 73 & Burundi & & $0-12$ & Bonnefille and Chalie 2000 & 74 & Black Sea & & $1-12$ & Bahr et al. 2005 \\
\hline 75 & SE Europe & $\Delta \mathrm{T}$ & $0-12$ & Davis et al. $2003 a$ & 76 & Kola & $\delta^{18} \mathrm{O}$ & $0-9$ & Jones et al. 2004 \\
\hline 77 & Lk Victoria & Diatoms & $0-10$ & Stager et al. 2003 & 78 & Lk Malawi & $\mathrm{Si}$ & $0-12$ & Johnson et al. 2002 \\
\hline 79 & Lk Malawi & MAR & $0-12$ & Johnson et al. 2002 & 80 & SE Mediterranean & $\delta^{18} \mathrm{O}$ & $0-4$ & Schilman et al. 2003 \\
\hline 81 & SE Mediterranean & $\delta^{18} \mathrm{O}$ & $0-4$ & Schilman et al. 2003 & 82 & Soreq $\mathrm{Cv}$, Israel & $\delta^{18} \mathrm{O}$ & $0-12$ & Bar-Matthews et al. 1999 \\
\hline 83 & Red Sea & $\delta^{18} \mathrm{O}$ & $1-12$ & Seeberg-Elverfeldt et al. 2004 & 84 & Lk Sim, Kenia & $\delta^{18} \mathrm{O}$ & $1-10$ & Barker et al. 2001 \\
\hline
\end{tabular}

5, 287-326, 2009

Mid-Holocene climate reorganization

K. W. Wirtz et al.

\section{Title Page}

\section{Abstract}

Conclusions

Tables

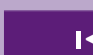

14

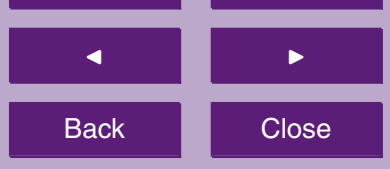

Full Screen / Esc

Printer-friendly Version

Interactive Discussion 
Mid-Holocene climate reorganization

Table 2. Continued.

\begin{tabular}{|c|c|c|c|c|c|c|c|c|c|}
\hline No & Site & Proxy & Per & Reference & No & Site & Proxy & Per & Reference \\
\hline 85 & Lk Hall, Kenia & $\delta^{18} \mathrm{O}$ & $1-12$ & Barker et al. 2001 & 86 & Kilimanjaro & $\delta^{18} \mathrm{O}$ & $0-12$ & Thompson et al. 2002 \\
\hline 87 & Lk Abhe, Ethiopia & Level & $0-10$ & Gasse 2000 & 88 & Somalia & $\delta^{18} \mathrm{O}$ & $0-10$ & Jung et al. 2004 \\
\hline 89 & Qunf Cv, Oman & $\delta^{18} \mathrm{O}$ & $0-11$ & Fleitmann et al. 2007 & 90 & Oman & $\delta^{18} \mathrm{O}$ & $3-8$ & Fleitmann et al. 2003 \\
\hline 91 & Arabian Sea & $\delta^{18} \mathrm{O}$ & $0-11$ & Gupta et al. 2003 & 92 & Arabian Sea & SSTW & $0-12$ & Schulz 1995 \\
\hline 93 & NE Arabian Sea & $\delta^{18} \mathrm{O}$ & $0-12$ & Doose-Rolinski et al. 2001 & 94 & NW Siberia & $\mathrm{T} 7$ & $0-4$ & Hantemirov and Shiyatov 2002 \\
\hline 95 & E Arabian Sea & $\delta^{18} \mathrm{O}$ & $0-10$ & Sarkar et al. 2000 & 96 & Lk Issyk-Kul, Kyrgyzstan & $\delta^{18} \mathrm{O}$ & $3-9$ & Ricketts et al. 2001 \\
\hline 97 & Tibet & $\delta^{18} \mathrm{O}$ & $0-12$ & Fontes et al. 1996 & 98 & Dunde, China & $\delta^{18} \mathrm{O}$ & $0-9$ & Jung et al. 2004 \\
\hline $\begin{array}{l}99 \\
101\end{array}$ & $\begin{array}{l}\text { Komsomolskaia } \\
\text { NW China }\end{array}$ & $\begin{array}{l}\delta^{2} \mathrm{H} \\
\mathrm{P}(\mathrm{AC})\end{array}$ & $\begin{array}{l}0-12 \\
2-11\end{array}$ & $\begin{array}{l}\text { Masson et al. } 2000 \\
\text { Herzschuh et al. } 2004\end{array}$ & $\begin{array}{l}100 \\
102\end{array}$ & $\begin{array}{l}\text { N Siberia } \\
\text { NW China }\end{array}$ & $\begin{array}{l}\text { Pollen } \\
P(E f)\end{array}$ & $\begin{array}{l}0-11 \\
2-11\end{array}$ & $\begin{array}{l}\text { Andreev et al. } 2003 \\
\text { Herzschuh et al. } 2004\end{array}$ \\
\hline 103 & Dongge Cv, China & $\delta^{18} \mathrm{O}$ & $0-9$ & Wang et al. 2005 & 104 & Vostok, Antarctica & $\delta^{2} \mathrm{H}$ & $0-12$ & Petit et al. 1999 \\
\hline 105 & N China & Clay & $0-10$ & Xiao et al. 2002 & 106 & S China & Moisture & $0-10$ & Liu et al. 2000a \\
\hline 107 & Xiangshui Cv, China & $\delta^{18} \mathrm{O}$ & $0-6$ & Zhang et al. 2004 & 108 & S China Sea & $\delta^{18} \mathrm{O}$ & $3-12$ & Kienast et al. 2001 \\
\hline 109 & N China & GSD & $5-10$ & Jin et al. 2004 & 110 & S China Sea & $\delta^{18} \mathrm{O}$ & $0-12$ & Wang et al. 1999 \\
\hline 111 & Taiwan & LOI & $2-12$ & Huang et al. 1997 & 112 & S China Sea & SSS & $0-9$ & Jung et al. 2004 \\
\hline 113 & S China Sea & $\delta^{18} \mathrm{O}$ & $0-11$ & Wang et al. 1999 & 114 & S China Sea & Silt & $0-12$ & Wang et al. 1999 \\
\hline 115 & S China Sea & $\delta^{18} \mathrm{O}$ & $0-12$ & Wang 1999 & 116 & Dongge Cv, China & $\delta^{18} \mathrm{O}$ & $0-12$ & Yuan et al. 2004 \\
\hline $\begin{array}{l}117 \\
119\end{array}$ & $\begin{array}{l}\text { Sulu Sea } \\
\text { E China Sea }\end{array}$ & $\begin{array}{l}\delta^{18} \mathrm{O} \\
\text { SST }\end{array}$ & $\begin{array}{l}4-12 \\
1-12\end{array}$ & $\begin{array}{l}\text { Rosenthal et al. } 2003 \\
\text { Sun et al. } 2005\end{array}$ & $\begin{array}{l}118 \\
120\end{array}$ & $\begin{array}{l}\text { W Pacific } \\
\text { E China Sea }\end{array}$ & $\begin{array}{l}\delta^{18} \mathrm{O}(81) \\
\text { SST }\end{array}$ & $\begin{array}{l}0-12 \\
0-11\end{array}$ & $\begin{array}{l}\text { Stott et al. } 2004 \\
\text { Fengming et al. } 2008\end{array}$ \\
\hline 121 & W Pacific & $\delta^{18} \mathrm{O}$ & $0-12$ & Rosenthal et al. 2003 & 122 & W Pacific & $\delta^{18} \mathrm{O}(76)$ & $0-12$ & Stott et al. 2004 \\
\hline 123 & NW Pacific & $\%$ Nitzschia & $0-7$ & Shimada et al. 2004 & 124 & NW Pacific & \%Ozeanica & $0-7$ & Shimada et al. 2004 \\
\hline 125 & S Australia & $\mathrm{T}$ & $0-4$ & Cook et al. 2000 & 126 & Tasmania & $\mathrm{T}$ & $0-4$ & Cook et al. 2000 \\
\hline 127 & Tasmania & $\mathrm{T}$ & $0-4$ & Cook et al. 2000 & 128 & SW Australia & Particles & $1-12$ & Stanley and Deckker 2002a \\
\hline 129 & Taylor dome & $\delta^{18} \mathrm{O}$ & $0-12$ & Grootes et al. 1994 & 130 & Taylor dome & $\delta^{2} \mathrm{H}$ & $0-12$ & Steig et al. 1998 \\
\hline
\end{tabular}

K. W. Wirtz et al.

\begin{tabular}{|c|c|}
\hline \multicolumn{2}{|c|}{ Title Page } \\
\hline Abstract & Introduction \\
\hline Conclusions & References \\
\hline Tables & Figures \\
\hline I4 & \\
\hline 4 & $>$ \\
\hline Back & Close \\
\hline Full Screen / Esc
\end{tabular}

Printer-friendly Version

Interactive Discussion 


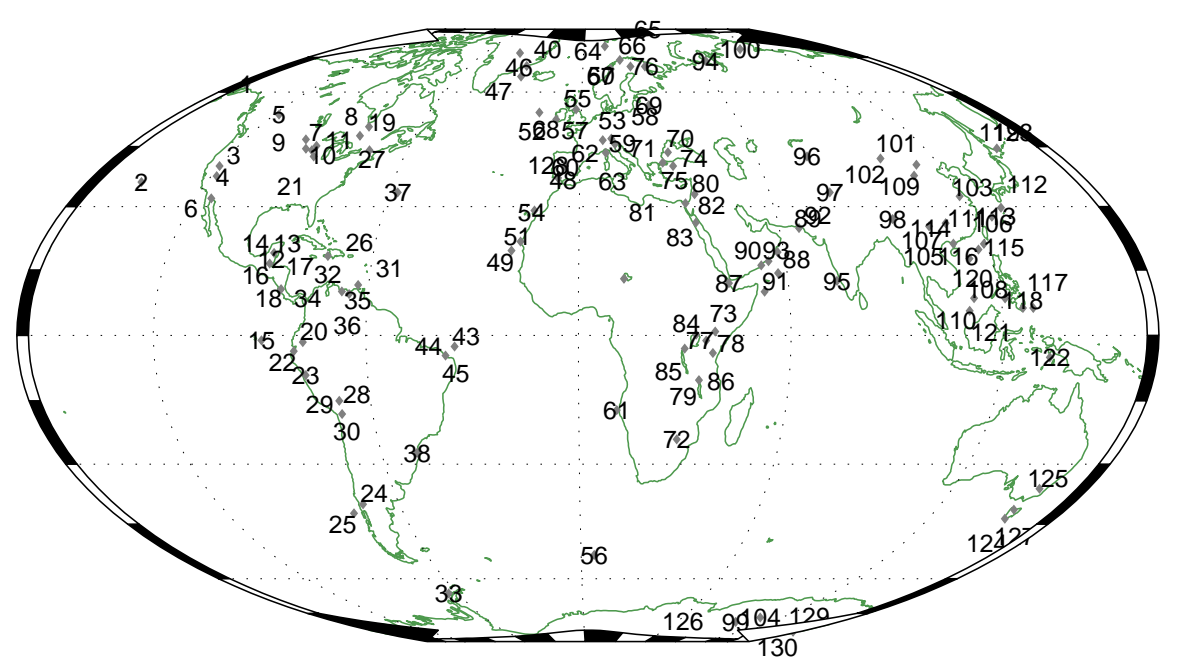

Fig. 1. Global distribution of high-resolution proxy time series used in this study. Numbers of the 130 records (109 sites) refer to Table 2.

\section{Mid-Holocene climate} reorganization

K. W. Wirtz et al.

\begin{tabular}{|c|c|}
\hline \multicolumn{2}{|c|}{ Title Page } \\
\hline Abstract & Introduction \\
\hline Conclusions & References \\
\hline Tables & Figures \\
\hline I4 & \\
\hline 4 & $\triangleright \mathbf{I}$ \\
\hline Back & Close \\
\hline Full Screen / Esc
\end{tabular}

Printer-friendly Version

Interactive Discussion 

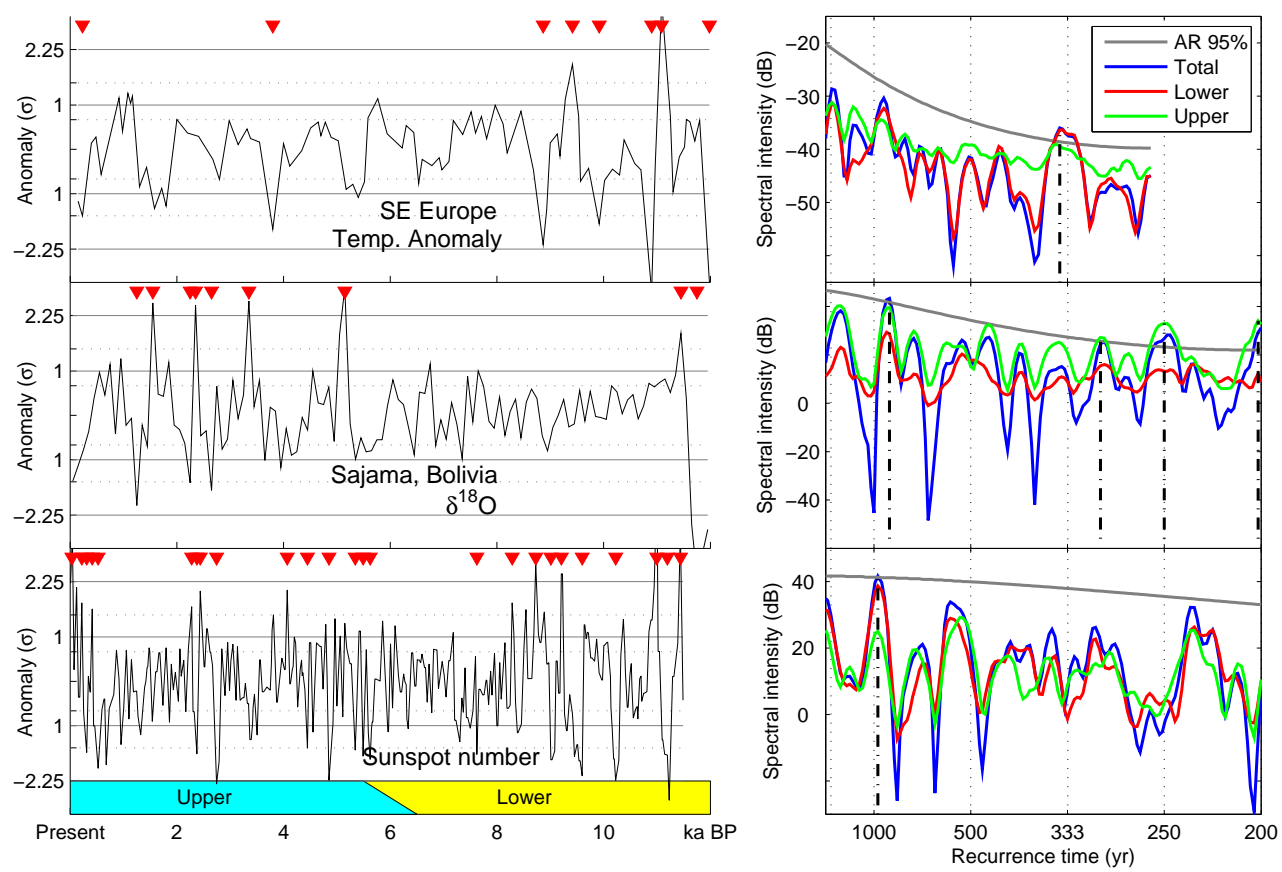

5, 287-326, 2009

Mid-Holocene climate reorganization

K. W. Wirtz et al.

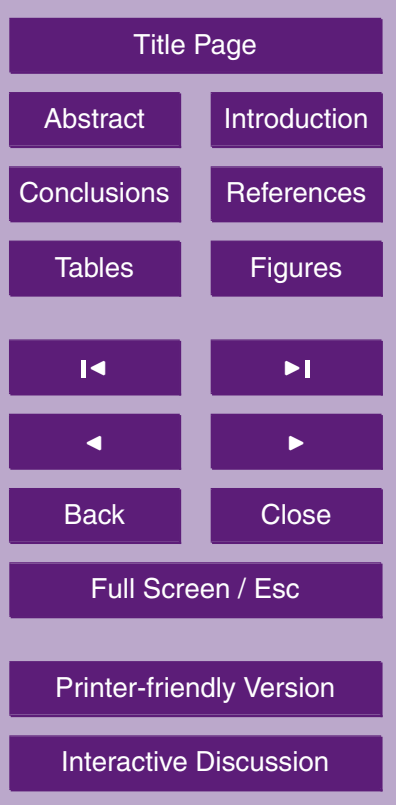

Fig. 2. Three selected records: Temperature reconstruction for Southeast Europe, (Davis et al., 2003b), isotopic oxygen at Sajama, Bolivia (Thompson et al., 2003b) and sunspot number from Greenland ice cores (?). Left: De-trended and normalized data. Non-cyclic events according our definition with $p_{a}=1.5$ are marked with red triangles. Right: Spectral amplitudes after applying the Lomb-Scargle transformation (black: total record, red: bootstrapping of upper interval, thus indicating periodicity confined to the Lower Holocene, green: Upper Holocene spectrum). Dashed lines indicate significant frequencies.

Interactive Discussion 


\section{5, 287-326, 2009}

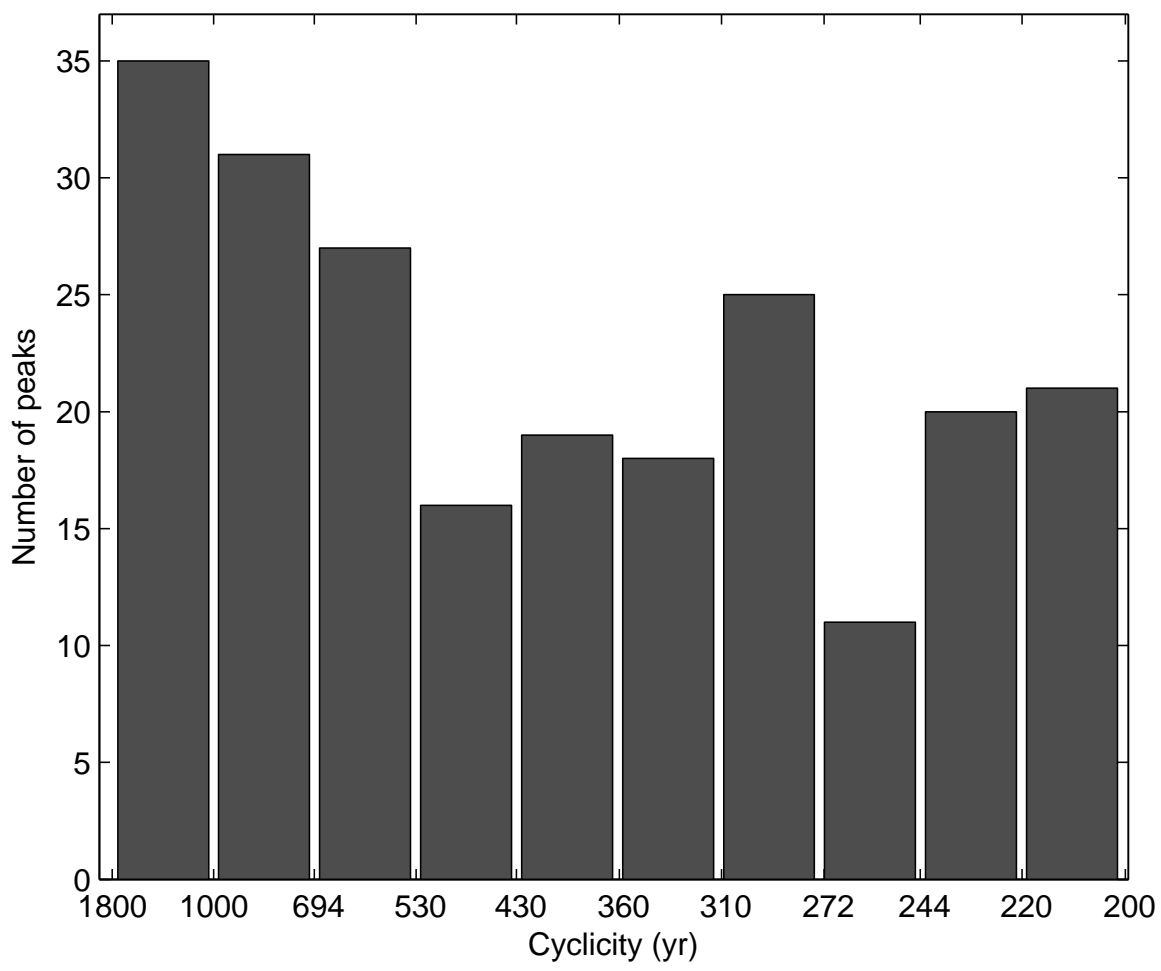

Mid-Holocene climate reorganization

K. W. Wirtz et al.

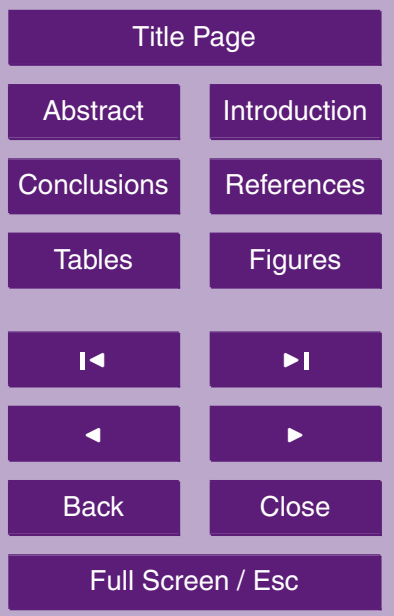

Printer-friendly Version

Fig. 3. Histogram of dominant modes in all 130 records.

Interactive Discussion

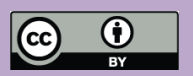




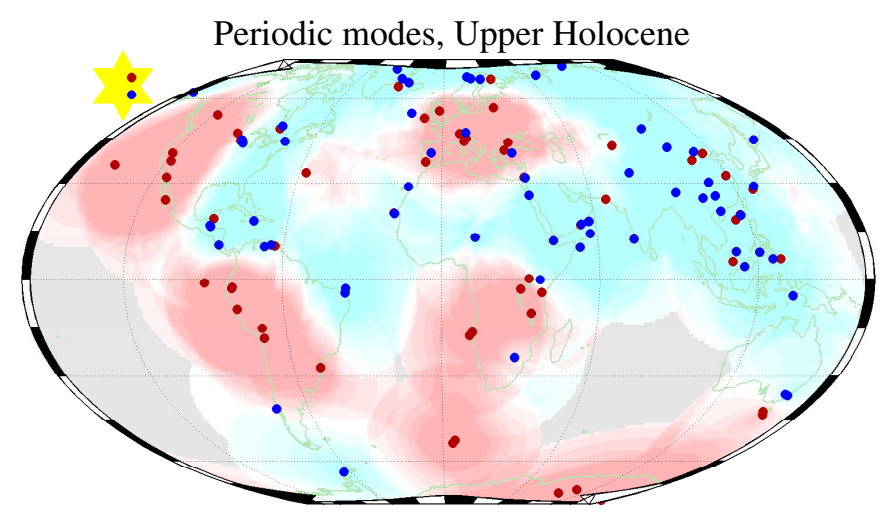

5, 287-326, 2009

Mid-Holocene climate reorganization

K. W. Wirtz et al.

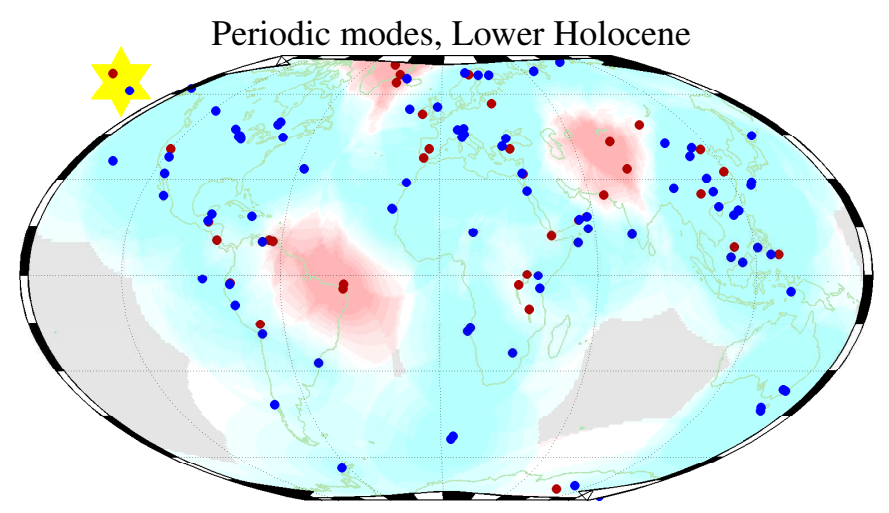

Title Page

Abstract

Conclusions

Tables

Tables
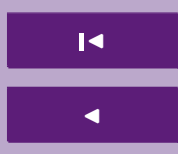

Back

Introduction

References

Figures

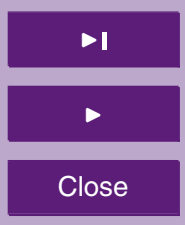

Full Screen / Esc

Printer-friendly Version

Interactive Discussion

Fig. 4. Sites with significant periodicity (red, without: blue) in the Upper and Lower Holocene. For spatial extrapolation see Methods, results for proxies related to solar activity are displayed in the yellow polygon.

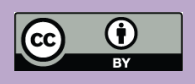




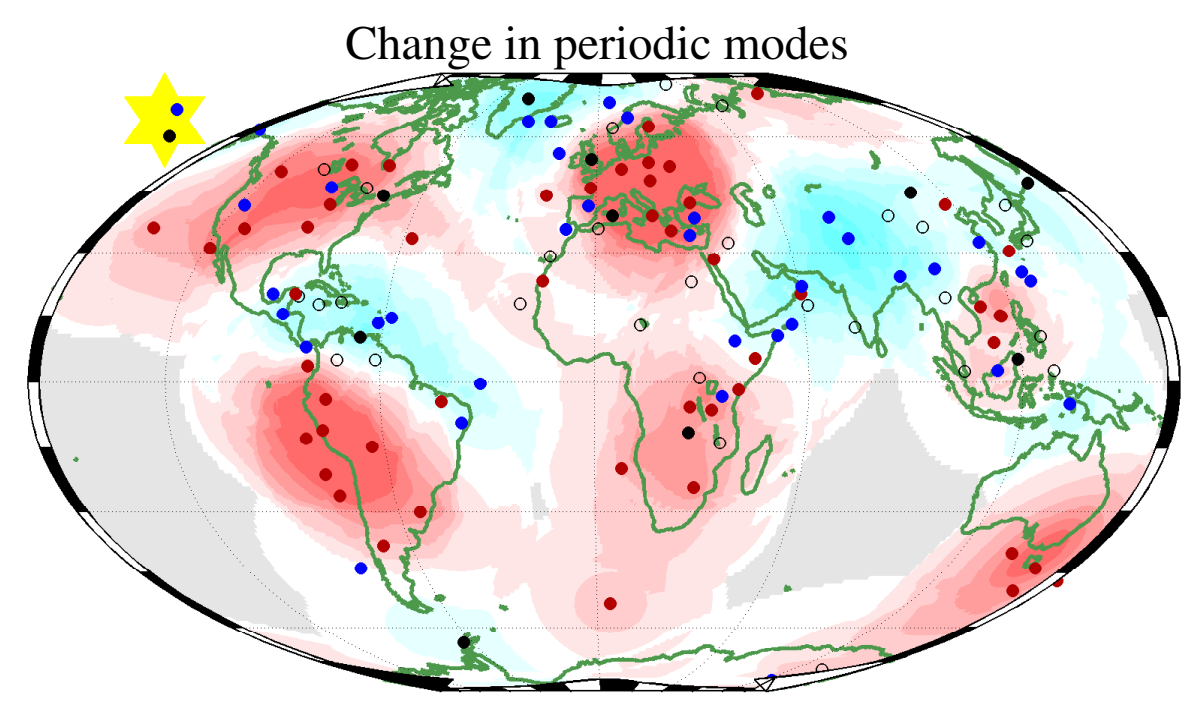

Fig. 5. Change in periodic fluctuations from the Lower to the Upper Holocene (positive change: red, negative: blue, no significance: empty circle, significant mode without change: filled black).

\section{Mid-Holocene climate} reorganization

K. W. Wirtz et al.

\begin{tabular}{|c|c|}
\hline \multicolumn{2}{|c|}{ Title Page } \\
\hline Abstract & Introduction \\
\hline Conclusions & References \\
\hline Tables & Figures \\
\hline I4 & \\
\hline 4 & $-\mathbf{I}$ \\
\hline Back & Close \\
\hline Full Screen / Esc
\end{tabular}

Printer-friendly Version

Interactive Discussion 


\section{$5,287-326,2009$}

\section{Mid-Holocene climate}

reorganization

K. W. Wirtz et al.

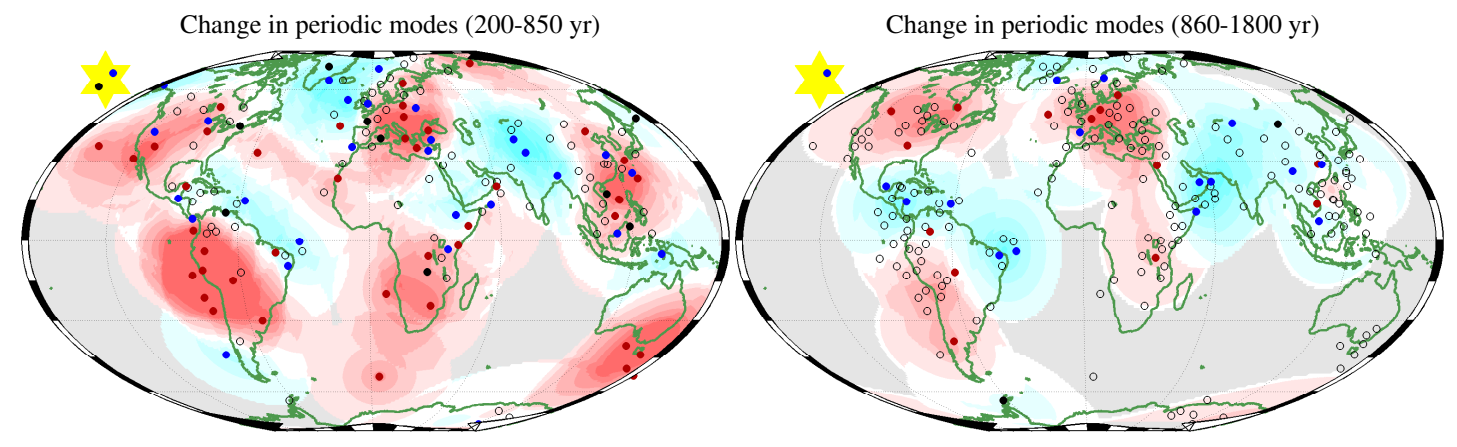

Fig. 6. Change in periodic fluctuations from the Lower to the Upper Holocene separated according spectral interval (for symbols, see Fig. 5).

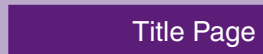

\section{Abstract} Introduction

Conclusions

References

Tables

Figures

\begin{tabular}{cc|}
\hline I4 & $\rightarrow$ \\
\hline 4 & $\bullet$ \\
\hline Back & Close \\
\hline
\end{tabular}

Full Screen / Esc

Printer-friendly Version

Interactive Discussion 


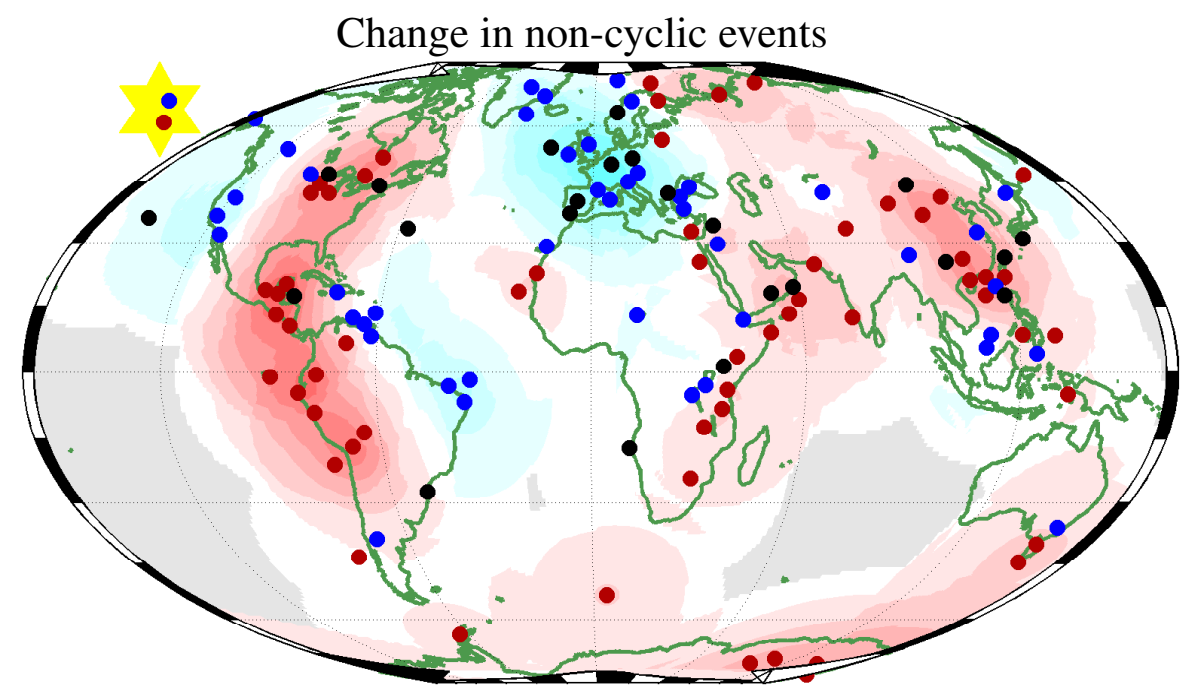

Mid-Holocene climate reorganization

K. W. Wirtz et al.

\begin{tabular}{|c|c|}
\hline \multicolumn{2}{|c|}{ Title Page } \\
\hline Abstract & Introduction \\
\hline Conclusions & References \\
\hline Tables & Figures \\
\hline I4 & \\
\hline 4 & $\triangleright \mathbf{I}$ \\
\hline Back & Close \\
\hline Full Screen / Esc
\end{tabular}

Fig. 7. Negative and positive Mid-Holocene change in non-cyclic frequency (number of events per millennium). Red areas collect sites where non-cyclic frequency increased by more than 0.1 events $\mathrm{kyr}^{-1}$ more in the Upper compared to the Lower Holocene. In blue areas, anomaly frequency decreases by more than 0.1 events $\mathrm{kyr}^{-1}$.

Printer-friendly Version

Interactive Discussion 